\title{
Affordable Housing and the Environment In Buffalo, New York
}

July 9, 2007

\author{
Sam Magavern \\ Clinical Instructor \\ University at Buffalo Law School \\ 507 O'Brian Hall \\ Buffalo NY 14260-1110 \\ (716) $645-5131$ \\ sm292@buffalo.edu
}

with Todd Chard, Sean Cooney, Kimberlee DeFazio, Erik Faleski, Andrew Florance, Constance Giessert, Andre Lindsay, Martha McNeill, Mary O'Donnell, Mark Smith, Lauren Weiss, Gary Wilson, and Katie Woodruff 
Table of Contents

1. Brief Summary 4

2. Summary of Recommendations 6

3. Housing $=$ Pollution 9

4. The Greening of the Affordable Housing Movement 11

5. A More Accurate Cost/Benefit Analysis 13

6. Buffalo's Housing Patterns 16

a. Abandonment and Sprawl 16

b. Unaffordability and Homelessness 19

c. Environmental Health and Racial Disparities 21

7. Buffalo's Comprehensive Plan 25

8. Green Affordable Housing in Buffalo: Current Status 29

9. A Greener Housing Policy 33

a. Basic Premises 33

b. Funding Shifts 33

c. Funding Criteria 36

$\begin{array}{ll}\text { d. Regulations } & 37\end{array}$

e. Making Existing Housing and Lots Greener 41

i. Conservation Education 41

ii. Weatherization 42

iii. Preservation 44

iv. Deconstruction and Recycling 52

v. Vacant Lots and Brownfields 55 
f. Making New Housing Units Greener 60

i. Rehab versus New Build 61

ii. Location 62

iii. Density 62

iv. Size 63

$\begin{array}{ll}\text { v. Materials } & 65\end{array}$

$\begin{array}{ll}\text { vi. Energy } & 68\end{array}$

vii. Water Management 71

10. Conclusion 75

11. Selected Sources 76

12. Student Papers 77

13. Acknowledgments 78 


\section{Brief Summary}

Buffalo is suffering from severe housing and environmental problems, many of which overlap. New housing continues to sprawl into the suburbs and exurbs, despite a large surplus of housing units in Buffalo, where the City plans to demolish 10,000 units in the next ten years. In general, housing is not being designed, built, or renovated in an environmental manner. Our out-dated housing policies and choices contribute significantly to pollution, both locally and globally: the region gets a failing grade for air quality; the city has 68 sewage overflows per year; and residential energy use is the largest source of the city's greenhouse gas emissions. Air pollution affects people with low incomes the most severely, and, with the advent of climate change, it has the potential to make millions of people homeless around the globe.

Greening our state and local affordable housing policies is a win/win strategy that will reduce both pollution and poverty. If we do more realistic cost/benefit analyses that cover the whole life of the home, we will see that greener policies - especially regarding energy efficiency and alternative energy - make housing more affordable even as they lessen environmental harms.

The State of New York, the City of Buffalo, and the non-profit community should adopt policies and practices that

- Require and reward greater energy efficiency in housing;

- Add to the incentives for alternate energy use;

- Educate the public and promote energy conservation;

- Promote water conservation and rain water control;

- Reduce sprawl and revitalize the city; 
- Preserve more housing from foreclosure, disrepair, and abandonment;

- Increase funding for preservation, weatherization, and renovation and prioritize them over new construction;

- Prioritize deconstruction and recycling of housing materials over demolition;

- Re-use vacant lots and brownfields for gardens, farms, parks, and greenways. 


\section{Summary of Recommendations}

\section{City of Buffalo}

1. Fulfill the commitment Buffalo made in the U.S. Mayors' Climate Protection Agreement to reduce carbon dioxide emissions; use greener affordable housing programs as one strategy to reduce emissions.

2. Shift more housing funds to preservation, rehabilitation, and weatherization of existing housing units. These strategies are more cost-effective, more environmental, and more beneficial to the City than programs to construct new housing or programs to subsidize home-ownership.

3. Use CDBG or other funds to create a funding pool aimed specifically at green affordable housing.

4. Institute green criteria for all grants, loans, and other housing development incentives provided by the City.

5. Institute a public education campaign to teach residents how to lower their utility bills and reduce pollution through home energy conservation.

6. Provide more funding, coordination, marketing and educational support for the reuse of vacant lots for community gardens, urban farms, wildflower gardens, greenways, and other environmentally sound uses.

7. Expand land-banking efforts based on the study of successful programs in Flint, Atlanta, and other cities in order to more quickly and effectively recycle vacant buildings and lots for productive uses. Consider partially or fully forgiving more tax liens in order to facilitate the return of properties to productive uses.

8. Prioritize deconstruction over demolition of buildings in the City. Develop a system to identify which structures should be bid for deconstruction and which for demolition. Make policy changes to heighten the incentives for demolition contractors to recycle and re-use more building materials.

9. Create a plan and seek federal and state funding to address the 56 identified brownfields in the City. Assess each brownfield for the use of phytoremediation: the process by which appropriate plants can be used to absorb contaminants from polluted soils.

10. Amend the building code to heighten environmental standards in areas such as insulation, energy-efficient heating/cooling and lighting, water efficiency, and storm-water run-off. Reward green building projects with lower fees, faster permit processing, and other incentives. 


\section{State of New York}

1. Provide more state funding to the Weatherization Assistance Program: the most efficient way possible to reduce pollution and make low-income housing more affordable at the same time.

2. Designate more state affordable housing funding specifically for green housing.

3. Amend the building code to heighten environmental standards in areas such as insulation, energy-efficient heating/cooling and lighting, water efficiency, and storm-water run-off.

4. Create a separate, less stringent, rehabilitation code modeled after New Jersey's.

5. In the Low Income Housing Tax Credit and other funding programs, increase the number of points awarded for environmentally-friendly features such as rehab over new construction, energy and water efficiency, location near mass transit, and the use of recycled and non-toxic materials.

6. Pass legislation modeled on Maine's to require landlords to disclose energy costs to tenants before signing a lease, so that landlords have incentives to weatherize units even if tenants pay the utility bills.

7. Pass legislation modeled on Minnesota's to allow tenants and city attorneys to sue landlords in simple and fast court procedures to obtain repairs and avert condemnations.

8. Develop strong anti-sprawl legislation and policies and target incentives, subsidies, and government spending in urban cores.

9. Provide funding to move all the abandoned properties controlled by the state Municipal Bank Bond Agency (MBBA) back into productive use within one year.

10. Provide the City of Buffalo with sufficient funds to rehabilitate all abandoned housing units that are salvageable within one year.

11. Provide the City of Buffalo with sufficient funds to deconstruct or demolish all housing units that are not salvageable within one year.

12. Pass legislation making it easier for the City to land bank and recycle abandoned properties.

13. Pass legislation to reduce mortgage foreclosure and abandonment by prohibiting predatory lending, funding mortgage foreclosure prevention programs, and prohibiting "flipping." 


\section{Non-Profits and Housing Providers}

1. Buffalo Niagara Medical Campus. Work with the University at Buffalo, the Fruit Belt neighborhood, the City, and others to create a "Healthy Homes" project that combines green housing with community gardening, fruit trees, and nutrition programs.

2. Homeless Alliance of Western New York. Incorporate green criteria into the HUD Continuum of Care funding process for shelters, transitional housing, and supportive housing projects.

\section{Buffalo Municipal Housing Authority, Belmont Shelter, Habitat for Humanity, PUSH, and Other Housing Providers.}

a. Use rehabilitation of existing buildings instead of new construction whenever possible.

b. Site housing near mass transit and in walkable neighborhoods.

c. Link housing to urban farming and gardening projects.

d. Consider building "Katrina" cottages and other radically smaller houses when doing infill housing in Buffalo.

e. Use non-toxic, recycled, renewable, local, durable, easily maintained and easily recycled materials.

f. Expand on current energy efficiency efforts. Explore passive solar design, daylighting, greater insulation, LED and compact fluorescent lighting and other methods which, even in cases where they cause higher up-front costs, pay for themselves over time and create healthier environments for the residents, the community, and the planet.

g. Use alternative energy sources such as solar electricity, solar hot-water heating, and windmills.

h. Use water-conserving devices and include a rain-water management plan with environmentally friendly landscaping in every project.

4. Buffalo First. Create a Buffalo First Carbon Offsets program, offering individuals and organizations that wish to offset their carbon emissions a way to do so locally. Devote the money raised through the offsets to grants for emission reduction in local affordable housing through weatherization, solar power, solar hot water heating, energy efficient appliances and lighting, etc. 


\section{Housing $=$ Pollution}

Housing $=$ pollution. For many of us, including me, this is a hard equation to grasp. We think about housing as good and pollution as bad, and we resist linking the two. Our homes do not look as if they were polluting: they do not belch out bad-smelling fumes like steel plants and automobiles. Few of us think, when we flip on a light switch, that we bear any responsibility for a mountain being dynamited in West Virginia or a town being flooded on the coast of Indonesia.

But the facts are staring us in the face.

- Homes use $21 \%$ of the nation's energy, most of which is produced by burning coal.

- Homes directly cause about 17 percent of total greenhouse emissions in the United States each year. ${ }^{1}$

- Our 114.1 million homes cause an average of 24,000 pounds of carbon dioxide emissions per home each year. ${ }^{2}$

- $\quad 35 \%$ of each family's greenhouse gas emissions come from household operations, as opposed to $32 \%$ from transport and $12 \%$ from food. $^{3}$

- In the City of Buffalo, residential energy use is the largest contributor to greenhouse gas emission (34\%), well ahead of industrial uses (24\%), commercial establishments $(20 \%)$, and personal vehicles $(14 \%){ }^{4}$

In fact, these figures are deceptively low, because another aspect of our housing - its sprawl - causes much of the pollution that our vehicles produce.

Our housing choices are an important part of the reason that the United States, with only $5 \%$ of the world's population, contributes $25 \%$ of its greenhouse gasses. The

\footnotetext{
${ }^{1}$ HUD Public Housing Energy Clearinghouse, http://www.hud.gov/offices/pih/programs/ph/phecc/

${ }^{2}$ Center for Policy Alternatives, "Progressive Agenda for State Housing Policy 2007," p. 16, citing U.S. Department of Energy, "Short-Term Energy Outlook 2006."

${ }^{3}$ Michael Brower, The Consumer's Guide to Effective Environmental Choices: Practical Advice from the Union of Concerned Scientists (Random House, 1999), p. 51

4 “The Queen City in the 21st Century: the Buffalo Comprehensive Plan," p. 40
} 
average American uses twice as much fossil fuel (coal, oil, and gas) as the average British person, and 2.5 times as much as the average Japanese person. ${ }^{5}$

And while global warming is, appropriately, at the top of the list of environmental concerns, the way that we build and operate our homes damages the environment in many other important ways, causing smog, deforestation, water pollution, soil contamination, and habitat loss. Our housing choices cause indoor pollution as well. Poor ventilation and toxic building materials, for example, can cause sickness and exacerbate problems such as asthma, the most common chronic disease among American children.

${ }^{5}$ Brower, p. 5 


\section{The Greening of the Affordable Housing Movement}

For those active in affordable housing, environmental concerns have not always been a high priority. Understandably, affordable housing policy has tended to focus on ending homelessness and fighting poverty by building and rehabbing units as quickly and inexpensively as possible.

In recent years, however, the affordable housing community has been turning green. Green affordable housing developments have sprouted up across the country. Most dramatically, the National Resources Defense Council and Enterprise Community Partners have launched the Green Communities Initiative, a five-year, \$550 million commitment to build more than 8,500 environmentally friendly affordable homes. Habitat for Humanity International now has an Environmental Initiative, and many Habitat chapters have created green homes. Many other non-profit developers have built or rehabbed green affordable housing.

What has caused this sea change? Affordable housing developers increasingly recognize that greener housing helps them to reach their goals.

- Energy efficiency, while it may produce higher up-front costs, increases affordability over the long run. Because low-income families spend roughly $25 \%$ of their incomes on energy each year, reducing energy bills is crucial to keeping housing affordable. ${ }^{6}$

- Greener housing means healthier housing: better indoor air quality, walking neighborhoods, and, increasingly, better access to homegrown or fresh produce key considerations for low-income residents plagued with asthma, respiratory ailments, obesity, diabetes, and other ills connected to their housing situations.

- No part of the world, and no aspect of life, will be insulated from the effects of climate change. The Intergovernmental Panel on Climate Change predicts that

\footnotetext{
${ }^{6}$ Meg Power, "FY 2006 Energy Bills Forecast: the Impact on Low-Income Consumers," p. 2, available at http://www.opportunitystudies.org/repository/File/weatherization/energy-bills-and-burden.pdf
} 
sea levels will rise 7 to 23 inches by $2100 .^{7}$ Currently, 634 million people live in coastal areas threatened by rising sea levels. ${ }^{8}$ The U.N. also estimates that 50 million people may be displaced by desertification in the next ten years, a crisis caused mainly by climate change. ${ }^{9}$

- Hurricane Katrina gave dramatic proof that it is people in poverty who will be made homeless by the droughts, hurricanes and rising ocean levels created by global warming. In a bitter irony, the poorest people on earth, who have contributed the least to global warming, will be the most devastated. ${ }^{10}$

In short, reducing pollution turns out to be essential in preventing homelessness. Every non-green home we build is contributing to global warming trends which will, if not reversed quickly, leave millions homeless around the world.

\footnotetext{
${ }^{7}$ See http://topics.nytimes.com/top/news/science/topics/globalwarming/index.html. See also Intergovernmental Panel on Climate Change, Report of Working Group 1, available at www.ipcc.ch. ${ }^{8}$ Thomas Wagner "Many Large Cities at Risk of Rising Seas," Washington Post, March 29, 2007.

${ }^{9}$ Elizabeth Rosenthtal, "Likely Spread of Deserts to Fertile Land Requires Quick Response, U.N. Report Says," NY Times, June 28, 2007.

${ }^{10}$ Andrew Revkin, "Poor Nations to Bear Brunt as World Warms," NY Times, April 1, 2007; see also Intergovernmental Panel on Climate Change, "Climate Change 2007: Impacts, Adaptation and Vulnerability," available at www.ipcc.ch.
} 


\section{A More Accurate Cost/Benefit Analysis}

Most of the environmental issues with affordable housing do not pose a real conflict of values. In other words, on most of the relevant issues, we do not need to weight costs to plants, animals, and natural features against costs to humans. Even if we cared only about direct costs to humans, we should green our affordable housing. If we fail to see this, it is because the cost-benefit analysis we are doing is not truly realistic: it excludes data about long-term costs, health costs, and costs to other people, including people in other parts of the world.

The first step toward a more accurate cost/benefit analysis is the simplest and most powerful. We need to measure not just the costs of building or rehabbing a home, but also the costs of operating it, repairing it, and - eventually - recycling or demolishing it. After factoring in these costs and benefits, green strategies that once seemed expensive are revealed as bargains. Even strategies with high up-front costs, such as solar panels, more than pay for themselves over the life of the building.

A comprehensive life-cycle analysis of sixteen green affordable housing projects found an average net present value benefit of $\$ 15,363$ per unit from the use of green techniques. ${ }^{11}$ The average benefit to the resident was $\$ 12,637$; the average benefit to the developer was $\$ 2,725$. To achieve these benefits, the developers paid an upfront cost, or "green premium," averaging $2.4 \%$ of total development costs. ${ }^{12}$ On average, the developer still came out ahead. But even in those cases where the developer failed to recoup the green premium, the residents recouped it many times over. Thus, for

\footnotetext{
${ }^{11}$ William Bradshaw et al, "The Costs and Benefits of Green Affordable Housing," New Ecology Institute (2005), p. 166.

${ }^{12}$ Id., p. 163.
} 
governmental or non-profit housing developers, whose goal is affordability for residents, not quick profits for the developer, the benefits of green design were enormous.

The second step in a more realistic cost/benefit analysis is to consider the health costs to residents. For example, paints and wood products with toxins that can trigger asthma attacks and increase cancer risks impose substantial health costs on residents (and on all of us, through higher health insurance premiums and taxes). Locating housing where residents can walk or ride bikes lowers health costs from obesity, diabetes, hypertension, and other diseases. Combining housing with access to fresh, affordable organic produce yields health benefits through better nutrition.

The third step is to look at impacts on other people: other residents of the area, other people in the world, and people yet to be born. If an inefficient house requires more coal to be burned, that means higher health costs due to air pollution, and a wide range of costs to people all over the world due to global warming. There is no cost-free burning of fossil fuels; no cost-free use of virgin lumber; no cost-free use of water; no cost-free extraction of metals from under the earth; no cost-free destruction of wetlands and woodlands.

When this, more thorough cost/benefit analysis is done, one finds that many housing choices and designs that today are considered radical or visionary are in reality simply prudent. The State of California developed a cost/benefit analysis of green building that included environmental and health costs. California's study concluded that the overall financial benefits of green state buildings, including lower emmissions and better health and productivity, were $\$ 48.87$ per square foot for LEED certified and LEED 
silver buildings, and $\$ 67.31$ for LEED gold and platinum buildings. ${ }^{13}$ (LEED, or Leadership in Energy and Environmental Design, is the most common rating system for green building). As California's study showed, today's "normal" building practices are actually wildly impractical and expensive, while green building practices offer a huge return on a small investment.

13 "The Costs and Financial Benefits of Green Buildings: a Report to California's Sustainable Building Task Force" (2003), p. ix 


\section{Buffalo's Housing Patterns}

\section{a. Abandonment and Sprawl}

The most striking fact about Buffalo's housing is the huge number of abandoned homes and lots. In 2000, there were 10,170 vacant residential lots and 8,684 abandoned structures in the city alone. The number of vacant housing units in the city went from 15,535 in 1990 to 22,854 in 2000 (15.7\% of total housing units). ${ }^{14}$ For the region as a whole, the number of vacant units went from 30,713 in 1990 to 42,564 in 2000.

The City demolished 4,581 housing units during fiscal years 2000 - 2006 at a total expense of $\$ 23,548,952 .^{15}$ The average cost of demolition has risen from $\$ 5,311$ in 2000 2001 to $\$ 13,100$ in $2005-2006$, primarily due to stricter state asbestos regulations. ${ }^{16}$ The City's latest Five-Year Consolidated Plan included \$3.8 million per year in vacant land management, $\$ 7.6$ million per year in vacant building stabilization/management, and $\$ 5.4$ million per year in demolition. ${ }^{17}$ The City estimates its five-year out-of-pocket costs from an average vacant property at a minimum of $\$ 20,000$ per property, for a total annual cost of $\$ 10$ million.

For example, 304, or 43\%, of all fire calls between January 1, 2006 and February 15, 2007 occurred in vacant structures, costing the City roughly $\$ 1,408$ per fire to respond. ${ }^{18}$ This figure probably underestimates the full costs of these fires. In 2006, 50 out of the 334 injuries suffered by Buffalo fire fighters occurred at vacant structures. ${ }^{19}$ Vacant structures are particularly dangerous in fires because their deteriorated condition makes

\footnotetext{
${ }^{14}$ Not every vacant housing unit is abandoned. Some are for-sale, for-rent, or vacant for another reason. But of Buffalo's vacant units, $43.7 \%$ are classified as "other," by the Census, indicating a high degree of abandonment. See National Vacant Properties Campaign, "Blueprint Buffalo," p. 3.

${ }^{15}$ City of Buffalo Fiscal Year 2007-2008 Budget Overview, p. 19

${ }^{16}$ Id.

${ }^{17}$ City of Buffalo Five Year Consolidated Plan (2003-2008), p. 12

${ }^{18}$ Id., p. 20.

${ }^{19}$ Maki Becker, “Arson fires: the firefighters' nightmare,” Buffalo News, June 15, 2007.
} 
them more prone to collapse. Sixty-five percent of all fires in the city are arsons, and most arsons take place in vacant buildings. In 2006, 250 of 399 arsons were in vacant buildings. ${ }^{20}$ Arson, of course, causes criminal enforcement and other costs in addition to fire-fighting costs.

The city's abandoned housing creates a vicious circle of depressed property values, flight from the city, and further abandonment. What is causing this massive abandonment? Some of the factors are:

- Continued loss of population to the suburbs and other states;

- High unemployment and concentrated poverty;

- Predatory lending, flipping, and other exploitative practices;

- Disinvestment by absentee landlords.

The development pattern of the region is sprawl without growth. The city of Buffalo emptied out between 1950 and 2000, with its population declining from 580,132 to 292,648. Many of those households moved to the suburbs. The portion of Erie County outside of Buffalo grew from 319,106 to 657,617 in that same time period, even though the metro region grew only from $1,089,230$ to $1,170,111 .^{21}$ From 1990 to 2,000, only 3,656 new units were built in the city, many of them public or publicly subsidized. During that same time, the housing stock of suburban/rural Erie County expanded by 20,134 units. $^{22}$

\footnotetext{
${ }^{20} \mathrm{Id}$.

${ }^{21}$ Final Report, Erie-Niagara Framework for Regional Growth (October 2006), p.8, available at www.regionaframework.com.

${ }^{22}$ Comprehensive Plan, p. 24.
} 
The city has continued to lose population in the new century, falling by another $5.7 \%$ to 276,059 as of mid-2006. ${ }^{23}$ In the year 2005 , only 110 new, privately owned units were authorized for building permits in Buffalo, ranking the city $64^{\text {th }}$ out of 67 cities with population over 250,000. By contrast, Cleveland had 443, Milwaukee had 784, and Newark had 2,071. ${ }^{24}$ The median year that Buffalo's housing was built is 1939, making Buffalo's housing stock the oldest of the 67 major cities. ${ }^{25}$

From 1950 to 2000 , while the regional population grew by only $7 \%$, the urbanized area nearly tripled, from 123 square miles to 367 square miles. From 1980 until 2006, when the region's population was declining by $5.8 \%$, the urbanized area grew $38 \%{ }^{26}$ As of $2000,41 \%$ of the households in the metro area were living at least 10 miles from the central business district. ${ }^{27}$ Between 1984 and 1999, the average number of miles driven each day increased by $50 \%$, from 10 to 15 miles. ${ }^{28}$ The annual cost of traffic congestion per peak traveler for 2003 was $\$ 224 .{ }^{29}$ Nearly $82 \%$ of Erie County commuters drive alone to work - even higher than the national average of $77 \% .^{30}$ Between 1990 and 2000, school transportation expenses in Erie and Niagara Counties increased 60\%, while the number of students increased less than $7 \%$. $^{31}$

While commute times have lengthened and jobs have moved to the suburbs and exurbs, in the city many households lack vehicles. The Census reports that $31.4 \%$ of the

\footnotetext{
23 "Widespread population drops found in WNY," Business First of Buffalo," June 28, 2007. Inner ring suburbs and rural areas are also losing population; it is only outer-ring suburbs such as Amherst, Clarence, Lancaster, Wheatfield and Orchard Park that are gaining population

${ }^{24}$ www.dataplace.org

${ }^{25}$ www.dataplace.org

${ }^{26}$ Final Report, Erie-Niagara Framework for Regional Growth (October 2006), p. 15, available at www.regionalframework.com.

${ }^{27}$ www.diversitydata.com, Harvard School of Public Health

${ }^{28}$ Erie-Niagara Framework for Regional Growth, p. 26

${ }^{29}$ www.diversitydata.com, Harvard School of Public Health

${ }^{30}$ Fred O. Williams, "WNY Commuters begin to consider car pooling," Buffalo News, June 3, 2007.

31 "At Taxpayers' Expense: How Government Policies Encourage Sprawl in Erie and Niagara Counties," p. 8, League of Women Voters (2006 Revised Edition).
} 
city's households - 7,438 owner-occupants and 31,122 renting households - have no

vehicle available. $^{32}$

\section{b. Unaffordability and Homelessness}

At first glance, Buffalo's affordable housing situation appears paradoxical: how could a city with surplus housing stock, a low median rent (\$472), and the lowest median home value of any major city $(\$ 59,300),{ }^{33}$ also have a severe homelessness problem, with 2,100 people staying outside, in emergency shelters, or transitional housing programs on any given night? ${ }^{34}$ The City estimates an unmet need of 212 emergency shelter beds, 589 transitional housing units, and 453 permanent housing units for its Homeless and Special Needs population. It estimates a need for 11,838 new affordable units for very lowincome households. $^{35}$

One obvious cause for homelessness is extreme poverty. In the city of Buffalo, $26.9 \%$ of the population is living below the federal poverty line. ${ }^{36}$ Buffalo is the fifth poorest city in the nation. ${ }^{37}$ Buffalo's median household income for renters is $\$ 19,155^{38}$ Thus, despite relatively low rents, $48.5 \%$ of Buffalo renters are paying more than $30 \%$ of their income toward rent - which means that they lack affordable housing and are at risk

\footnotetext{
${ }^{32} 2000$ Census figures, available from http://factfinder.census.gov

${ }^{33} 2000$ Census figures, available from http://factfinder.census.gov. See also "Buffalo has nation's lowest home values," Business First of Buffalo, May 24, 2005.

34 "PRISM: A Community Solution to Homelessness," p. 2, available at http://www.wnyhomeless.org/sitepages/publications/prism/Plan.pdf

${ }^{35}$ City of Buffalo Five Year Consolidated Plan (2003-2008), pp. 25, 27. Oddly, given this call for added affordable units, the City's Comprehensive Plan calls for reducing the number of public housing units from 7,000 to 5,000, which would mean a loss of 2,000 federal housing subsidies that cost the City nothing and add greatly to the net disposable income of 2,000 residents.

${ }^{36} 2005$ figures; see "Poverty: A State of Extremes," Institute Policy Brief (October 2006), available at http://regional-institute.buffalo.edu/includes/UserDownloads/PolicyBrief_Poverty.pdf The federal poverty line is currently $\$ 10,210$ per year for a single person and $\$ 17,170$ for a family of three.

${ }^{37} 2005$ Census figures; see http://www.usccb.org/cchd/povertyusa/povfact6.shtml.

${ }^{38} 2005$ figures, available at $\underline{h t p: / / f a c t f i n d e r . c e n s u s . g o v ~}$
} 
of homelessness. ${ }^{39}$ Even in the metro region as a whole, $42.5 \%$ of renters pay over $30 \%$ of their income for rent. As a result, the Buffalo region ranks ninth worst in the nation for housing affordability. ${ }^{40}$

While rents in Buffalo are low, utility costs are high. Metro area housing costs are roughly $8 \%$ below the national average, but utility costs are nearly $30 \%$ above the national average. ${ }^{41}$ Since roughly $75 \%$ of Buffalo renters pay their own utilities, the housing is less affordable than it first appears. ${ }^{42}$ Nationwide, the average home spends $\$ 1,500$ per year on energy bills, but in Buffalo, the average is $\$ 2,267 .{ }^{43}$ While people in poverty use somewhat less energy, their utility bills are a huge burden. In the midAtlantic states of Pennsylvania, New Jersey, and New York, the average energy bill for a household in poverty is $\$ 1,740$, or $39 \%$ of the household's annual income. ${ }^{44}$

Not only renters, but also homeowners, suffer from affordability problems in Buffalo: problems exacerbated by the high number of high cost - and often predatory loans made in the area. More than 3,000 households in the Buffalo region entered foreclosure in $2006{ }^{45}$ Nearly $14 \%$ of the area's subprime loans were in default at the close of 2006. Aside from the Gulf Coast areas struck by hurricanes, the Buffalo region had the highest number of defaults on prime loans in the first three months after the loan

\footnotetext{
${ }^{39} \mathrm{http}$ ://factfinder.census.gov, DP-4, Profile of Selected Housing Characteristics: 2000

40 www.diversitydata.org, Harvard School of Public Health, 2000 data

41 State of the Region Project, Cost of Living Report, 2/05

42 www.epodunk.com

${ }^{43}$ DOE Home Energy Saver, http://hes3.lbl.gov/hes/hes.taf?f=top

${ }^{44}$ Meg Power, "FY 2006 Energy Bills Forecast: the Impact on Low-Income Consumers," p. 4. The MidAtlantic has the very highest energy burden for people living in poverty; nation-wide, the energy burden for people in poverty is $25 \%$. For people not living in poverty, the average energy burden is $5 \%$. Id. at Appendix B, p. 7.

45 Jonathan D. Epstein, "Buffalo has high rate of default and foreclosure on mortgages," Buffalo News, June 29, 2007
} 
closed in $2006 .{ }^{46}$ In the third quarter of 2006, the region had the state's second highest foreclosure rate for all loans - a rate more than double that of the previous quarter. ${ }^{47}$

\section{c. Environmental Health Problems and Racial Disparities}

Buffalo's low-income residents also suffer from a host of health problems exacerbated by the environmental problems in their housing and their overall environment. Asthma is the most common chronic disease among American children, and asthma attacks are often triggered by mold, dust, cockroaches, and other housing repair problems, as well as by air pollution. ${ }^{48}$ Buffalo's old housing stock suffers from severe repair problems that can aggravate asthma, and the Buffalo region receives a "failing" grade from the American Lung Association for ozone smog pollution. ${ }^{49}$ Erie County is the fourth worst county in the state in terms of number of people suffering from bad air quality. ${ }^{50}$ A New York state study that assessed 3,008 children in Buffalo found that $26 \%$ of them had asthma. ${ }^{51}$ Among the risk factors identified were dampness in the home, frequent truck traffic in the neighborhood, and proximity to an active industrial facility emitting ammonia. A second study of 5,427 Buffalo children found a crude asthma incidence of $8.2 \%$ and an overall asthma prevalence of $22.3 \%$. Among the risk

\footnotetext{
${ }^{46} \mathrm{Id}$.

${ }^{47} \mathrm{Id}$.

${ }^{48}$ The overall prevalence of asthma among U.S.children is estimated between $4.3 \%$ and $6.9 \%$. See Jamson Lwebuga-Mukasa, "A school-based asthma intervention program in the Buffalo, New York schools," Journal of School Health, January 2002.

49 John F. Bonfatti, “Air Quality Improves in Region,” Buffalo News, May 1, 2007.

${ }^{50}$ In the most recent year measured, Erie County had 6,589,051 person-days exceeding the national ambient air quality standard. This measures the number of days when pollutants exceeded the NAAQS, multiplied by the number of people in the affected area. See www.scorecard.org for the data.

51 "Childhood Asthma and Environmental Risk Factors in the City of Buffalo, New York: Information Sheet," New York State Department of Health (January 2005).
} 
factors identified were cockroaches in the home. According to a third study, focused on Buffalo's east side, $11 \%$ of the children and $7 \%$ of the adults had asthma. ${ }^{52}$

Lead poisoning is perhaps the most prominent environmental health hazard for children in the region. Lead poisoning usually comes from exposure to lead paint in older housing that is not well-maintained. The Erie County prevalence rate of confirmed elevated blood levels is $6.84 \%$, compared with a New York State rate of $3.02 \%{ }^{53}$ The county has roughly 20,000 housing units with a high risk of lead hazards. ${ }^{54}$ Buffalo's old housing stock and high poverty levels give it the worst lead problems in the region and perhaps the state. Regionally, of the 25 local census tracts that are classified as high risk, 23 are in the city. The city accounts for $95 \%$ of all new cases with hazardous blood-lead levels. Thirteen percent (13\%) of the children in Buffalo screened for lead in 1994 had elevated levels of lead: a total of 1,116 children. Buffalo has three of the five zip codes with the highest elevated blood levels in New York State. ${ }^{55}$

Buffalo's housing and environmental problems are not evenly distributed: they fall most heavily on people with low incomes and especially people of color. For example, the four zip codes with the highest rates of lead poisoning are on the predominantly African-American east side of the City of Buffalo, with incidence rates between three and five times higher than Erie County's average. ${ }^{56}$ Hispanic residents

\footnotetext{
52 "Results of Landmark Study of East Side Community Health Needs to be Released by Black Leadership Forum," www.kaleidahealth.org/news/archive/0501/052201.asp

${ }^{53} \mathrm{http}$ ://leadconnections.org/DidYouKnow.php. According to another source, 33\% of the children in Erie County have lead levels that are too high, and in Buffalo, almost $65 \%$ of children have lead toxicity. See "Housing Highlights," Neighborhood Legal Services (February/March 2000), available at www.nls.org/housing/febmar00.htm.

54 "Pollution rankings: lead hazards by county" at www.scorecard.org.

55 "Healthy Homes," University at Buffalo Graduate Planning Studio, http://www.ap.buffalo.edu/\%7Ebmclean/lead/lead_context1.htm

56 "State of the Region: Lead Exposure in Children,", available at http://regionalinstitute.buffalo.edu/sotr/Indicator.cfm?Indicator=108e30d5-8253-4953-8fb2-ec7c1bc4fdf0.
} 
have the highest asthma rates in Buffalo, roughly twice that of other residents; the problem is particularly severe in west side neighborhoods close to the Peace Bridge complex and major roadways feeding into it. ${ }^{57}$ Between 1991 and 1996, 158 people died of asthma in western New York. Of these deaths, 50\% occurred in Buffalo (which has only $20 \%$ of the region's population). The two zip codes with the highest mortality were in African-American neighborhoods. ${ }^{58}$

Buffalo is the eighth most segregated metropolitan area in the nation ${ }^{59}$. Eightysix percent of the region's African-Americans are concentrated in the cities of Buffalo and Niagara Falls. Even within the city, segregation remains strong. For example, South Buffalo is $96 \%$ white and only $1 \%$ African-American, whereas the Masten Community is $87 \%$ African-American. ${ }^{60}$

While only $1.2 \%$ of the metro area's white residents live in very high poverty neighborhoods, $25.9 \%$ of Hispanic residents and $21.1 \%$ of African-American residents live in very high poverty neighborhoods. For whites, this level of poverty concentration is the $23^{\text {rd }}$ worst in the nation; for African Americans, it is the $7^{\text {th }}$ worst; and for Hispanics, it is the $4^{\text {th }}$ worst. $^{61}$ While the child poverty rate for white families in the region is $9.2 \%$, for African-Americans it is $44.3 \%$ and for Hispanics it is $46.5 \%{ }^{62}$

\footnotetext{
${ }^{57}$ Jamson S. Lwebuga-Mukasa et al, "Risk factors for asthma prevalence and chronic respiratory illnesses among residents of different neighborhoods in Buffalo, New York," Journal of Epidemiology and Community Heath; 2004; 58:951-957; and James S. Lwebuga-Mukasa and Paulette M. Niewczyk, "Crude Asthma Incidence Rates Among Buffalo NY Children," American College of Chest Physicians (2006), available athttp://meeting.chestjournal.org/cgi/reprint/130/4/237S-b

${ }^{58}$ John Patrick Almeida and Jamson S. Lwebuga-Mukasa, "Geographic Variations in Asthma Mortality in Erie and Niagara Counties, Western New York, 1991-1996," American Journal of Public Health, September 2001, Vol. 91, No. 9, 1394-1395

59 "The Queen City in the 21st Century: the City of Buffalo Comprehensive Plan," p. 20

${ }^{60}$ Id.

${ }^{61}$ www.diversitydata.org, Harvard School of Public Health.

${ }^{62}$ Id.
} 
One should note that the Buffalo region as a whole is much wealthier than one might expect. The region's total personal income - all the money earned by its residents in a given year - rose $7.5 \%$ between 2003 and 2005 to reach a total of $\$ 36.7$ billion. This ranks $48^{\text {th }}$ in the nation, a fairly appropriate spot for the $45^{\text {th }}$ largest metro area. ${ }^{63}$ How could it be, then, that the city itself has the fifth highest poverty rate in the nation? The problem is not so much the lack of resources as their highly unequal distribution in economic, spatial, and racial terms.

\footnotetext{
${ }^{63}$ G. Scott Thomas, "Buffalo edges up in income rankings," Business First of Buffalo, April 26, 2007.
} 


\section{Buffalo's Comprehensive Plan}

The City of Buffalo approved a Comprehensive Plan in February 2006. The Plan

describes itself as follows:

The Queen City in the 21st Century: the Buffalo Comprehensive Plan is the one plan for the City of Buffalo. It will be the preeminent legal document guiding all development in the City of Buffalo. It will provide the policy framework for all other local planning efforts including plans for downtown, neighborhoods, the waterfront, special districts and special purposes. There may be many plans in the city but they must be consistent with the one plan for Buffalo, the Comprehensive Plan. ${ }^{64}$

Given the centrality of the Plan, we should review it carefully for its consideration of housing and environmental issues.

According to the Plan, the City will "build a city that is a prosperous, green regional center providing livable communities for all its citizens. ${ }^{\circ 65}$ The first of four key principles guiding the Plan is that "Buffalo's future development should be sustainable, integrating economic, environmental and social concerns.",66

The Plan calls for initiatives to

- Reduce the consumption of energy, land and other non-renewable resources;

- Minimize the waste of materials, water, and other limited resources;

- Create livable, healthy and productive environments; and

- Reduce greenhouse gasses in order to assist in alleviating the impact of global climate change. ${ }^{67}$

Regarding water management issues, the Plan calls for "leadership in ensuring the clean-up and restoration of the Great Lakes ecosystem. ${ }^{68}$ It notes that an average of 68

\footnotetext{
${ }^{64}$ The Queen City in the 21st Century: the Buffalo Comprehensive Plan, p. 3

${ }^{65} \mathrm{Id}, \mathrm{p} .1$

${ }^{66} \mathrm{Id}$.

${ }^{67}$ Id., p. 39
} 
combined sewer overflow events happen in Buffalo each year, sending sewage into our local waterways. ${ }^{69}$

The Plan states that "more rapid assembly and clean-up of brownfield sites is urgently needed to support the City's and region's economic development program." ${ }^{\text {70 }}$ Forty-nine of Buffalo's 56 brownfields are located in its three Strategic Investment Corridors, ranging from five acres to nearly 160 acres and totaling almost 1,500 acres. $^{71}$

As the Plan notes, Buffalo signed the US Mayors Climate Protection Agreement, promising to reduce greenhouse gas emissions to 7\% below 1990 levels by 2012 . Buffalo has completed its emissions inventory, showing that residential energy use is the biggest source of greenhouse gas emissions (34\%) and that the City's municipal operations contribute about $15 \%$ of the City's total emissions. ${ }^{72}$ To this date, however, Buffalo has not announced a plan to reduce its emissions.

Buffalo residents are "substantially underserved by public parks," with only 5.1 acres of parkland per 1,000 residents, compared to an upstate New York average of 9.2 acres. $^{73}$ The Plan calls for an assessment of vacant spaces in the City for their environmental value and possible functions in the "green infrastructure, including re-use as parks, woodlots, greenways, or gardens." ${ }^{, 74}$ It also calls for a new "Olmsted Park" on a 150 acre brownfield north of William Street and west of Bailey Avenue. ${ }^{75}$

\footnotetext{
${ }^{68}$ Id., p. 5

${ }^{69}$ Id., p. 55

${ }^{70}$ Id., p. 16

${ }^{71}$ Id., p. 76

${ }^{72}$ Id., p. 40

${ }^{73}$ Id., p. 44. According to one source, Buffalo spends $\$ 6$ per resident on parks upkeep, in contrast to Seattle, which spends $\$ 245$ per resident. Lauren Weiss, "Environmentally Friendly Uses for Vacant Properties in Buffalo", p. 5, http://green-housing-buffalo.wikispaces.com.

${ }^{74}$ Comprehensive Plan, p. 50

${ }^{75}$ Id., p. 50
} 
In its section on Green Building, the Plan notes that buildings consume more than half the energy used worldwide and states that "green building techniques and codes should also be used in the design and construction of new structures as well as the retrofitting of existing buildings." T6 The Plan describes "intense interest in energy in the city and region for both economic and environmental reasons" and states that "energy conservation and development of alternative sources of energy can deliver benefits in both categories."77 Neighborhood plans should "promote energy conservation and use of alternative sources of energy."78

The Plan sets ambitious housing targets to begin in 2004:

- 500 units of new or converted housing per year for ten years;

- 500 units of rehabbed housing per year for ten years;

- 1,000 units of housing demolished per year for ten years;

- half of the new, converted, and rehabbed units to be located downtown or near downtown, with the other half targeted to areas of concentrated neighborhood investment (in schools, jobs, parks and waterfront). ${ }^{79}$

The Plan calls for "transit, pedestrian, and bicycle systems" that maximize access and mobility ... while reducing dependence upon the automobile." It asks for neighborhoods to be "compact, pedestrian-friendly, and mixed use," with many activities of daily living within walking distance" ${ }^{, 80}$ and "a range of parks, from tot-lots and village greens to ball fields and community gardens., ${ }^{, 81}$

\footnotetext{
${ }^{76}$ Id., p. 51

${ }^{77}$ Id., p. 56

${ }^{78}$ Id., p. 87

${ }^{79}$ Id., p. 90

${ }^{80}$ Id., p. 96

${ }^{81}$ Id., p. 96
} 
Finally, the Plan calls for an Environmental Management System and a "full-fledged Environmental Plan." The EMS would include a "comprehensive database, and a set of indicators that would allow the City and citizens to understand environmental conditions." $" 82$ To this writer's knowledge, the City has not yet acted to implement such a system or plan.

${ }^{82}$ Id., p. 101 


\section{Green Affordable Housing in Buffalo: Current Status}

Buffalo lags behind the rest of the nation in developing green affordable housing or green building of any kind. There are only a handful of LEED-certified buildings in the region: Audubon Machinery in North Tonawanda, the Niagara Falls Bridge Commission in the Town of Lewiston, the Creekside Village Community Center at the University at Buffalo in Amherst, and Harris Hill Fire Hall in Amherst. The United States Green Building Council lists only three LEED-Certified architects in Buffalo, compared with 17 in Cleveland and 22 in Pittsburgh - two comparably sized Rust Belt cities. ${ }^{83}$ While a small number of home-owners have "greened" their homes, no housing developer has produced a significant green project in the Buffalo region.

Perhaps the most important local initiative is the energy efficiency work being done by the Buffalo Municipal Housing Authority. The BMHA is the largest affordable housing provider in the region, with roughly 7,000 units. It is in the midst of a multi-year energy performance contract to increase energy efficiency in its existing buildings with insulation, weatherization, new heating systems, low-flow toilets, faucets, and showers, and other basic techniques. The first phase of the project is expected to save BMHA $\$ 7$ million in energy costs. ${ }^{84}$

Unlike some other housing authorities around the nations, BMHA has not attempted more adventurous green design techniques. The Boston Housing Authority has developed a green building at its Maverick Landing site that includes solar panels. ${ }^{85}$ Milwaukee's housing authority has developed Highland Gardens, which features the

\footnotetext{
${ }^{83}$ www.usgbc.org/myUSGBC/Members/MembersDirectory. The three firms in Buffalo are Kevin Connors and Associates, Stieglitz Snyder Architecture, and TRM Architect.

${ }_{84}$ www.hud.gov/offices/pih/programs/ph/phecc/eperformance/epcsuccess.cfm

${ }^{85} \mathrm{http} / / /$ www.hud.gov/offices/cpd/environment/library/maverick_landing.doc
} 
nation's largest residential green roof. In addition to the longer roof life, the green roof offers storm-water reduction, improved air quality, and a reduction of cooling costs by $12 \%$ and heating costs by $10 \%{ }^{86}$ And, as is discussed later in this essay, Seattle's public housing authority has created special "Breathe-Easy" housing units offering a healthier choice for asthma sufferers.

While BMHA has found ways to finance its energy-efficiency renovations, HUD policy hinders BMHA from fully replacing old units with new, energy-efficient units. While HUD allows housing authorities to capture the savings in utility bills when they do rehab, it does not provide comparable incentives for replacement. Currently, BMHA is exploring the replacement of the LBJ seniors apartment complex, which Medaille College would like to purchase. But, because HUD policy does not allow BMHA to profit from the energy savings that would result, BMHA is having difficulty making the project work. $^{87}$

Belmont Shelter, the largest non-profit housing developer in the region, has not done a significantly green project. ${ }^{88}$ The local Habitat for Humanity chapter, which produces about 16 homes per year, is green in the sense that it favors rehab over new construction, builds small, and uses energy efficient appliances, but it has not followed the example of other Habitat chapters around the nation in attempting deeper and more

\footnotetext{
${ }^{86}$ http://www.hud.gov/offices/pih/programs/ph/phecc/success/successarchive2.cfm. For green design resources and information geared to public housing authorities, see http://globalgreen.org/phaenergytoolbox/tech roofing.htm.

${ }^{87}$ Personal communication, Modesto Candelario, Assistant Director, BMHA

${ }^{88}$ Mark C. Smith, "Belmont Shelter Corporation and Green Design," p. 3, http://green-housingbuffalo.wikispaces.com.
} 
innovative green measures such as solar power, super insulation, or green landscaping and storm water management. ${ }^{89}$

One of the greener housing developments in Buffalo is a four-plex on the west side owned by People United for Sustainable Housing Buffalo (PUSH). ${ }^{90}$ PUSH bought an abandoned building from the City's foreclosure sale for $\$ 6,000$ and used a large contingent of youth labor from the neighborhood to rehabilitate it. The PUSH house incorporates R-30 insulation, Energy Star windows, an Energy Star furnace, on-demand water heaters, compact fluorescent lighting, non-toxic paints, and ceiling fans. PUSH did the project without taking on any debt, at a cost of roughly $\$ 28,750$ per unit. PUSH has purchased another multi-unit building nearby and has plans to incorporate more green features into its next project. $^{91}$

Another new project with green features is the Villa Maria Senior Living Community currently under development in Cheektowaga. This 75-unit renovation of a former high school is green not only in that re-uses an existing facility (a former high school) but also in its use of geothermal heating/cooling. ${ }^{92}$ Other promising developments in Buffalo include the formation of Buffalo ReUse, a non-profit dedicated to dismantling and recycling, instead of demolishing, old structures, ${ }^{93}$ and the growing

\footnotetext{
${ }^{89}$ Martha R. McNeill, "Buffalo Habitat for Humanity: the Challenges and Prospects of Green Building," pp. 8-11, http://green-housing-buffalo.wikispaces.com.

${ }_{90}$ See Mary O’Donnell, "PUSH Buffalo's Community Housing Cooperative: a Case Study in Green Building Rehabilitation," http://green-housing-buffalo.wikispaces.com.

${ }^{91}$ See also Mark Sommer, "Co-op dwellers pile up nest eggs," Buffalo News, July 5, 2007, describing how the PUSH tenants save for homeownership through the federal First Home Club program, in which $\$ 75$ per month of their rent is set aside and then matched on a 3-1 basis by M\&T Bank for 18 months.

${ }^{92}$ Sharon Lindstedt, "Villa Maria to be converted to senior housing complex," Buffalo News, February 9 , 2006

${ }^{93}$ See Sean Cooney, "Residential Deconstruction in Buffalo: a Viable Alternative to Demolition," and Erik Faleski, "Deconstruction in Buffalo: Policy Alternatives," http://green-housing-buffalo.wikispaces.com
} 
number of community gardens and other creative re-uses of vacant lots in the city. ${ }^{94}$ But perhaps because the City, State, and philanthropic community have not yet made green housing a priority, Buffalo has a long way to go.

\footnotetext{
94 See Lauren Weiss, "Environmentally Friendly Uses for Vacant Properties in Buffalo," http://green-
} housing-buffalo.wikispaces.com 


\section{A Greener Housing Policy}

\section{A. Guiding Principles}

- Making affordable housing more energy-efficient and water-efficient should be a top priority, since it reduces poverty and pollution at the same time;

- Weatherizing, rehabilitating, preserving, and re-cycling existing housing stock is more efficient and environmental than demolishing existing housing stock and building new units;

- Cost-benefit analyses of housing decisions and policies should include the costs of operating, dismantling, and replacing housing, as well as the environmental and health costs on residents, community members, and others;

- Buffalo has more land than it needs for housing; it needs a comprehensive policy to re-use vacant lots for gardens, farms, greenways, wetlands, and other environmentally friendly uses that shore up property values and help the city retain and attract residents.

\section{B. Funding Shifts}

As a first step, the State, City, and philanthropic community should create funding pools dedicated solely to green affordable housing. Given the urgency of the need, the current lack of activity, and the dramatic benefits in reducing pollution and poverty simultaneously, it is hard to imagine a better use of funds. In Buffalo, where green housing is practically non-existent, it would be particularly useful to fund "demonstration houses" to educate local developers, builders, and residents on a variety of green strategies.

While Buffalo's Comprehensive Plan states that “green building techniques and codes should ... be used in the design and construction of new structures as well as the 
retrofitting of existing buildings," ${ }^{, 95}$ the City has not dedicated any funds to translate this goal into reality. To make this shift, the City should incorporate a green affordable housing fund into its next Five-Year Consolidated Plan, which governs the spending of over \$20 million per year in federal CDBG and HOME funds. Over \$6 million of Buffalo's \$14.89 million in 2007-2008 CDBG funding is devoted to "administration and planning" and "program delivery." Some of this remarkably high spending on overhead and staffing should go into direct grants and loans for green affordable housing. Similarly, the State needs to expand on its "Green Building Initiative" and reserve more of its affordable housing funding specifically for green projects.

Even small programs can have large effects in educating the public and providing incentives. Chicago recently offered twenty $\$ 5,000$ grants for green roofs on small-scale commercial or residential properties. Portland pays homeowners $\$ 53$ for each gutter downspout that gets disconnected. ${ }^{96}$ Minneapolis offers $\$ 20,000$ in micro-grants, each up to $\$ 1,000$, for projects to reduce global warming. ${ }^{97}$

Buffalo may need more upper-level staff devoted to housing in order to translate its goals into realities. Recently, several Common Council members suggested the need for a "Housing Czar" to attend to housing policy issues. Although the Mayor did not respond enthusiastically, the question deserves a closer examination. ${ }^{98}$

Beyond a doubt, Buffalo needs to put more focus, more staffing and more resources into environmental issues. The City does not appear to have a staff person

\footnotetext{
${ }^{95}$ Comprehensive Plan, p. 51

${ }^{96}$ Christopher Kloss and Crystal Calarusse, "Rooftops to Rivers: Green Strategies for Controlling Stormwater and Combined Sewer Overflows" (Natural Resources Defense Council, 2006), p. 16, available at http://www.nrdc.org/water/pollution/rooftops/rooftops.pdf

${ }^{97} \mathrm{http}: / /$ www.ci.minneapolis.mn.us/sustainability/MicroGrant_information2007.asp\#P7_1165

98 Brian Meyer, "Housing Czar Needed, Two Council Members Say" Buffalo News, Märch 29, 2007
} 
dedicated solely to the environment. The City's web-site does not reveal any major environmental program or initiative. By contrast, Minneapolis has two sustainability coordinators on staff and an ambitious set of sustainability goals for the city, which are benchmarked in an annual sustainability report. Each city department has sustainability goals and must include them in its annual business plan as part of the budget process. ${ }^{99}$ Similarly, Milwaukee's Mayor formed a "Green Team" to seek recommendations for greening Milwaukee, and the city now has an Office of Environmental Sustainability. ${ }^{100}$ Other examples abound: most cities devote substantially more resources to the environment issues than Buffalo. Although Buffalo faces severe budgetary constraints, many environmental measures are also cost-cutting measures. The University at Buffalo's tiny UB Green office, for example, has cut the University's energy costs by over $\$ 9$ million per year. ${ }^{101}$

The philanthropic community should also consider the benefits of green affordable housing in addressing poverty, health, and the environment simultaneously. One way to generate more funding is to create a local carbon offset program. Carbon offsets are an increasingly popular way for individuals, businesses, or organizations that want to become more "carbon-neutral" to offset some of their carbon emissions. One complaint about current carbon offset programs is that they are an unregulated hodgepodge. Some are for-profit and some are non-profit. Even some of the non-profits have worked with for-profit companies in ways that seem questionable: for example, providing subsidies to the enormously profitable Waste Management, Inc. to cover landfills and reduce methane emissions. For Buffalo-area organizations and individuals who would

\footnotetext{
${ }^{99} \mathrm{http}: / /$ www.ci.minneapolis.mn.us/sustainability/background.asp

${ }^{100} \mathrm{http}: / /$ www.city.milwaukee.gov/MilwaukeeGreenteamOr13213.htm

${ }^{101} \mathrm{http}: / /$ wings.buffalo.edu/ubgreen/content/aboutus/page1.html\#gbd
} 
like a reliable, easily-verifiable way to offset their emissions and help their own region, a "Buffalo First" offset program would be very attractive. The proceeds from the program could be used to improve energy efficiency and provide green energy for the housing of people with low incomes: for example, to add solar panels or solar hot water to a home being rehabilitated by a non-profit housing developer such as Habitat for Humanity, PUSH Buffalo, or Belmont Shelter. BuffaloFirst, a non-profit alliance of local, independent businesses, would make a natural home for a "Buffalo First" carbon offsets program.

\section{Funding Criteria}

The State, City, and other funders should apply green criteria to all affordable housing programs. Currently, Erie County's Continuum of Care funding for homelessness prevention does not incorporate green criteria beyond a mention of Energy Star in its materials. ${ }^{102}$ Similarly, the City of Buffalo does not appear to use any green criteria in allocating CDBG and HOME funds, despite the City's commitment to green building and sustainability in its Comprehensive Plan.

The State's Low Income Housing Tax Credit program awards only two points for environmental factors, and that is limited to the use of Energy Star appliances. Thus, New York was one of only six states given an F grade in a recent Global Green report on the greening of LIHTC programs. ${ }^{103}$ New York should emulate the six states receiving a

\footnotetext{
${ }^{102}$ See Andrew Florance, "Green Criteria for Affordable Housing," available at http://green-housingbuffalo.wikispaces.com, and Homeless Alliance of Western New York, "Continuum of Care: 2006, available at www.wnyhomeless.org.

103 "Making Affordable Housing Truly Affordable," pp. 15-16, available at http://www.globalgreen.org/greenbuilding/GAHI.html
} 
B Plus: California, Georgia, Arizona, Maryland, Massachusetts, and Texas, all of which have greened their criteria substantially.

New York's most recent Request for Proposals for affordable housing includes a Green Building Initiative, promising "additional rating points" under its Housing Trust Fund and HOME rating systems for projects demonstrating energy efficiency. However, it does not indicate how many additional points such projects will receive, nor does it address other environmental factors such as siting, water consumption, storm water retention, and the use of non-toxic materials. ${ }^{104}$

In developing green criteria, the Continuum of Care, the City, and the State need not re-invent the wheel. The Global Green Report has a comprehensive set of criteria and examples of best practices from other states. Policy-makers can also look to the Green Communities Criteria Checklist or the LEED Certification system and incorporate all or the most relevant aspects of these existing programs. ${ }^{105}$

\section{Regulations}

New York State and City of Buffalo should green their building codes, energy codes, and related regulations. Greener codes would benefit all housing, including affordable housing, by reducing operating costs, replacement and dismantling costs, health costs, and environmental costs.

Currently, New York State is operating with a 2001 version of the International Energy Conservation Code, which should be replaced with the 2006 version. Sharply rising energy costs make conservation all the more urgent. Between 2003 and 2005, the

\footnotetext{
${ }^{104} \mathrm{http}: / /$ www.dhcr.state.ny.us/ocd/pubs/pdf/rfp01.pdf,

${ }^{105}$ See www.greencommunitiesonline.org and www.usgbc.org.
} 
price of natural gas increased 37\% nation-wide. ${ }^{106}$ New York State residents pay the second highest residential electricity costs in the nation. ${ }^{107}$ The mid-Atlantic states have the highest energy burden for people living in poverty: $\$ 1,740$, or $39 \%$ of annual income. ${ }^{108}$ Energy costs are expected to continue to outpace inflation, making energy efficiency critical to housing affordability.

In addition to using the IECC, states and local governments have found other ways to adjust their regulations. Eighteen states and 59 towns and counties have incorporated LEED standards in their regulations in one way or another. ${ }^{109}$ Washington D.C. passed a Green Building Act requiring all private buildings over 50,000 square feet and all buildings that receive $20 \%$ or more public financing to meet green requirements. ${ }^{110}$ Boston became the first major city to require LEED certification for private developments, adding a provision to its zoning code that applies to all projects over 50,000 square feet. As Mayor Menino stated, green building is "good for your wallet," "good for the environment," and "good for people."111

In New York, the towns of Brookhaven, Babylon, Riverhead, Oyster Bay, and Southampton require all new homes to meet Energy Star standards, making them 30\% more efficient than current state code. While construction costs are estimated at $\$ 2000$ to $\$ 4000$ higher, annual energy savings are estimated at $\$ 780$, so that the housing is more affordable, not less. In addition, each Energy Star home releases 2.25 less tons of carbon

\footnotetext{
106 "Progressive Agenda for State Housing Policy 2007," p. 17, Center for Policy Alternatives, www.stateaction.org

107 "New York's Solar Road Map," Solar Initiative of New York (May 2007), p. 8, citing www.eia.doe.gov

${ }^{108}$ Meg Power, "FY 2006 Energy Bills Forecast: the Impact on Low-Income Consumers," p. 4 and Appendix B, p. 7

109 "City is Close to Mandating that Some New Buildings Go 'Green,"” Washington Post, 12/3/06 ${ }^{110}$ Id.

${ }^{111}$ Mayor Menino’s Green Building Task Force Report (2004), p. 1.
} 
dioxide into the air each year. ${ }^{112}$ The City of New York recently outlined its plans to rewrite its construction codes, including requirements for more efficient heating/cooling systems and a rule that all roofs be painted white or other reflective color. ${ }^{113}$

Buffalo should follow the lead of other cities and towns by incorporating LEED or Energy Star standards into its Code and adding simple requirements like reflectivecolored roofs. At the state level, one must ask: if it is viable and cost-effective to make buildings $30 \%$ more efficient, as towns like Babylon have shown, why not require that level of efficiency for all buildings? Why should the State remain a prisoner to the developers' habit of calculating only up-front costs, when it is far more realistic and economical to calculate costs over the life-cycle of buildings?

A simple regulatory measure is to require greater energy efficiency in light bulbs. Currently, compact fluorescent bulbs last ten times longer than incandescents, cause $70 \%$ less carbon emissions and save the owner roughly $\$ 62$ over the life of the bulb. ${ }^{114}$ The EPA estimates that if every household in the U.S. replaced 5 light bulbs with compact fluorescents, it would prevent more than 1 trillion pounds of greenhouse gas emissions. ${ }^{115}$ Compact fluorescents do have some flaws, however, including their use of the toxic element mercury.

The state of California has estimated that banning incandescents would keep 1.82 million metric tons of carbon dioxide emissions from entering the atmosphere. But because manufacturers may create an incandescent bulb as efficient as a compact

\footnotetext{
${ }^{112} \mathrm{http} / / / \mathrm{www}$.longislandnn.org/energy/eshomes.

${ }_{113}$ Diane Cardwell, "Bloomberg Outlines Plan to Rewrite City's Construction Codes," NY Times, May 4, 2007.

${ }^{114} \mathrm{http}: / /$ news.bbc.co.uk/1/hi/sci/tech/4667354.stm. According to another source, a CFL bulb" uses 75 percent less electricity, lasts 10 times longer, produces 450 pounds fewer greenhouse gases from power plants and saves consumers $\$ 30$ over the life of each bulb." Michael Barbero, "Wal-Mart Puts Some Muscle Behind Power-Sipping Bulbs,” New York Times, January 2, 2007

${ }^{115} \mathrm{http} / / / \mathrm{www} . e p a . g o v /$ climatechange/wycd/actionsteps.html
} 
fluorescent but without the mercury, the best approach is not to ban incandescents but simply to require a high level of efficiency. A bill before the California legislature takes this approach, and also deals with the issue of recycling compact fluorescent bulbs and disposing safely of their mercury. ${ }^{116}$

The State and City should also require greater water efficiency and better rain water management. The City of Minneapolis, despite having a much less severe sewer overflow problem than Buffalo, has instituted a five year plan to eliminate overflows. Minneapolis passed a "Rainleader Ordinance" in May 2003, which requires disconnection of all roof and area drains, or other storm water or clear water connections to the City's sanitary sewer system. ${ }^{117}$ Buffalo, a city in which the connecting of roof gutters to storm sewers remains common practice, should consider the Minneapolis example.

Other cities, including Chicago, Milwaukee, Pittsburgh, Seattle, and Washington D.C. have created programs to control combined sewer overflows. Many of the techniques used to capture storm water have other environmental benefits, as well. Green roofs, tree plantings, and pocket parks also reduce the heat in cities and thus the need for air-conditioning. Rain water captured in rain barrels and other ways can be used for irrigation, gardening, cleaning, cooling, and other uses which help to conserve fresh water and reduce the energy needed to pump it out of the lake and process it.

Regulatory changes can include incentives as well as prohibitions. Portland allows additional building square footage for buildings with green roofs, and Chicago

\footnotetext{
116 "Bill to ban sale of incandescent light bulbs advances", Marc Lifsher, Los Angeles Times, April 24, 2007). See also California State Assembly Bill 1109 (Huffman) - As Amended: April 12, 2007

${ }^{117} \mathrm{http}: / /$ www.ci.minneapolis.mn.us/cso/
} 
offers a density bonus for green roofs. ${ }^{118}$ Various cities, including Chicago, San Francisco, and Gainesville, offer "fast tracking" of building permits for green projects. Scottsdale offers expedited plan review for green buildings and, since 1999, has employed a green building inspector with special expertise. ${ }^{119}$

\section{Making Existing Housing and Lots Greener}

\section{i. Conservation Education}

The simplest, cheapest way to make housing more affordable and less polluting is to practice energy conservation. Most people with low incomes, whether owners or renters, pay their own utility bills. In Buffalo, $75 \%$ of renters pay their own utility bills. ${ }^{120}$ The City should use its media access and public education resources to encourage home energy conservation. The Mayor, in particular, should lend his prestige to such efforts. Through media stories, web-site, water-bill inserts, cable access, and other means, the City can make a dramatic difference. ${ }^{121}$

The leading energy uses in the average household are heating (39\%), major appliances (21\%), hot water (19\%), other appliances (15\%), and lighting (7\%). ${ }^{122}$ No-cost and low-cost measures to reduce energy use include the following:

- Turn hot water heater temperature down to 120 degrees;

\footnotetext{
${ }^{118}$ Christopher Kloss and Crystal Calarusse, "Rooftops to Rivers: Green Strategies for Controlling Stormwater and Combined Sewer Overflows" (Natural Resources Defense Council, 2006), p. 15, available at http://www.nrdc.org/water/pollution/rooftops/rooftops.pdf

${ }^{119} \mathrm{http} / / / \mathrm{www}$. iccsafe.org/news/green/0503BSJ35.pdf

${ }^{120} 2000$ census data, available at http://www.epodunk.com/cgi-bin/housOverview.php?locIndex=299.

${ }^{121}$ Katie Woodruff has developed a model conservation campaign for Buffalo with poster, tip sheet, and public service announcement, in "Home Energy Conservation," 2007, available at http://green-housingbuffalo.wikispaces.com.

${ }^{122}$ L. Walker, "Energy Conservation in the Home," Colorado State Extension, June 22, 2006.
} 
- Wrap hot water heater with insulation or an insulating blanket;

- Install a programmable thermostat and set thermostat to 68 degrees when home and 58 degrees when away or asleep;

- Weatherstrip windows and doors and seal cracks with caulk and spray-in foam;

- Wash clothes in cold water and line dry some or all of them;

- Install water-saving shower heads and faucets;

- When replacing appliances, look for the Energy Star label;

- Replace incandescent bulbs with compact fluorescents.

The City should explore getting a large quantity of free or heavily discounted compact fluorescent light bulbs to distribute as part of its home energy conservation campaign. A free product would help to make the educational campaign popular and appealing. Now that giant retailers such as Wal-Mart and HOME Depot are competing to demonstrate their green credentials, (Wal-Mart, for example, has pledged to sell 100 million compact fluorescent bulbs by the end of 2007) the opportunities for such collaborations abound. $^{123}$

\section{ii. Weatherization}

Expanding weatherization efforts may be the most efficient way to make housing greener and more affordable. Currently, the City spends no money on weatherization for people with low incomes. The federal Department of Energy's Weatherization Assistance Program (WAP) provides free weatherization assistance to people with low incomes. WAP funds flow through the State Division of Housing and Community

123 "Wal-Mart Pledges to Sell 100 Million Compact Fluorescents in '07," GreenBiz.com 
Renewal to local non-profits. The State adds a small amount of funding to WAP from the systems benefit charge included in utility bills. In Buffalo, the Matt Urban Center and Neighborhood Housing Services of South Buffalo administer the WAP programs. There is a long wait list for their services, despite the fact that they are barely publicized. $^{124}$

WAP is a remarkably effective program in making housing both more affordable and environmental. After WAP makes home improvements averaging about $\$ 2,800$ in cost, WAP recipients save $\$ 358$ per year in their utility bills. ${ }^{125}$ For households that use natural gas as their main heating fuel, as do $90 \%$ of Buffalo households, ${ }^{126}$ the savings are even larger, averaging $\$ 461 .{ }^{127}$

WAP recipients use $23 \%$ less heating fuel, reducing their average carbon dioxide emissions by 1,350 pounds per year. Each year, WAP reduces the national energy demand by the equivalent of 18 million barrels of oil. ${ }^{128}$ Weatherization programs also produce jobs for the local economy; the Department of Energy estimates that every $\$ 1$ million invested in WAP creates 52 jobs directly and 23 jobs indirectly. ${ }^{129}$ Given WAP's proven track record, the State should expand its WAP funding, and the City should devote a portion of its CDBG funds to WAP programs.

\footnotetext{
${ }^{124}$ The State agency NYSERDA also runs a weatherization program called "Assisted Home Performance" for families with more moderate incomes; in this program, the owner signs a contract with a certified energy performance contractor, and NYSERDA pays half the bill, up to a total of $\$ 5,000$. Lastly, the LIHEAP program, administered through the County, offers free furnace repair/replacement to eligible families along with financial assistance paying heating bills.

${ }^{125}$ Constance Giessert, "Weatherization Assistance and Low-Income Households," pp. 4, 7, http://greenhousing-buffalo.wikispaces.com.

${ }^{126} \mathrm{http}$ ://factfinder.census.gov, Profile of Selected Housing Characteristics, Buffalo, New York.

127 Meg Power, "FY 2006 Energy Bills Forecast: the Impact on Low-Income Consumers," p. 10

${ }^{128}$ Giessert, p.5

${ }^{129}$ Id., p. 10
} 
One problem with energy conservation is that if a landlord pays the utility bills, the tenant has no incentive to conserve energy - for example, by turning down the thermostat or washing laundry with cold water. But if the tenant pays the utility bills, the landlord has little incentive to weatherize the house and buy energy efficient appliances. In theory, housing with lower utility bills would be more attractive to tenants, but very few tenants learn about a unit's utility bills before deciding whether to rent.

Maine now requires landlords to provide a disclosure form to help potential tenants gauge the amount of energy a property consumes. The disclosure includes attributes of the property that effect overall energy use and energy efficiency such as insulation, windows, the heating system, and appliances. ${ }^{130}$ The State of New York should consider similar legislation, so that tenants can include energy costs when they judge how affordable a rental unit is, and landlords have more incentive to weatherize their units and buy energy efficient appliances, heating/cooling systems, and lighting systems. A better disclosure form than Maine's might include the unit's energy bills for the past year, along with a state-provided chart of average energy bills for various unit sizes.

\section{iii. Preservation}

Housing preservation is a large topic in and of itself, but it is crucial to greening city and state housing policies. There is no greater waste of environmental and fiscal resources than our present practice of abandoning and demolishing the city's housing while building new housing in the suburbs and exurbs. Between 1990 and 2000, over 20,000 new housing units were built in suburban/rural Erie County, even as the number

${ }^{130}$ Maine P.L. 2005, chapter 534; see www.maine.gov/mpuc/doing_business/forms/FactSheetPDF.pdf. 
of vacant units in Buffalo climbed from 15,535 to 22,854. The population of Erie County is shrinking, not growing. In other words, we are not building new housing to accommodate a larger population; rather, we are building new, more expensive housing in the suburbs to replace the more affordable housing we are abandoning in the city. ${ }^{131}$

Each time we build a new house instead of preserving an old house, we do double damage to the environment. With their large lot sizes, large houses, added infrastructure, lack of mass transit, and longer commute times, the new suburban developments tend to be both unaffordable and heavily polluting. New construction means loss of woodlands, wetlands and farm lands. New construction means more raw material extraction, deforestation, and mining. Demolishing old urban housing means losing valuable building materials and adding them to landfills. It means losing denser housing in walking neighborhoods with access to mass transit.

The State can take a broad array of actions to preserve urban housing and limit sprawl. ${ }^{132}$ One measure, pioneered by New Jersey, is to develop a building rehabilitation code that provides greater flexibility than existing codes, which are geared toward new construction. New Jersey's rehab code reduces rehabilitation costs by an average of $10 \%$. In the first year of the new code, New Jersey saw a $60 \%$ increase in rehabilitationrelated spending in its five biggest cities. ${ }^{133}$

The State can also preserve housing from deterioration and abandonment by protecting urban residents from predatory and irresponsible subprime lending.

\footnotetext{
${ }^{131}$ While it is true that due to demographic changes, the number of households in the region, as opposed to the number of people, did grow, housing construction in the 1990s still outpaced new households by a factor of four to one. See "Framework for Regional Growth," p. 18, at www.regionalframework.com.

${ }^{132}$ For more general policy recommendations, see "Restoring Prosperity: the State Role in Revitalizing America's Older Industrial Cities,” The Brookings Institution Metropolitan Policy Program (2007).

${ }^{133}$ For sources of this data and a model rehab coed, see "Progressive Agenda for State Housing Policy 2007," Center for Policy Alternatives, www.stateaction.org.
} 
Unaffordable mortgage costs and foreclosures are both major sources of housing disrepair and abandonment. In 2000, the Buffalo had 21,065 homes with mortgages, 1,958 homes with second mortgages, and 3,009 homes with home equity loans. ${ }^{134}$ In 2004, 20.6\% of conventional mortgage loans made in Buffalo were done by subprime lenders, and $30.3 \%$ of conventional re-financings were done by subprime lenders. ${ }^{135}$ Particularly with the rise in interest rates and collapse of the subprime market, many of these homes are being foreclosed or at risk of foreclosure. The Center for Responsible Lending estimates that one out of five subprime mortgages originated in 2005 and 2006 in the U.S. will end in foreclosure, ${ }^{136}$ and that nearly 2.4 million owners will lose their homes due to subprime loans made since $1998 .{ }^{137}$ As of March 2007, 19\% of all subprime loans were past due or in foreclosure. ${ }^{138}$

Defenders of current subprime lending practices often portray subprime lending as a vital form of access to home-ownership for people with low incomes. In fact, however, of 15.1 million subprime loans made between 1998 and 2006, only 1.4 million were for first time homebuyers. ${ }^{139}$ Most subprime loans are overpriced home equity loans with a bewildering array of confusing and misleading terms. For example, a study of subprime lending in Chicago found that most borrowers thought they were getting fixed rate loans, when in fact they were getting variable rates. ${ }^{140}$

Predatory lenders often target seniors, immigrants, people with disabilities, and people of color: people who lack good access to standard loan products and can be

\footnotetext{
${ }^{134} \mathrm{http}: / /$ www.city-data.com/housing/houses-Buffalo-New-York.html

${ }^{135} \mathrm{http}: / /$ www.dataplace.org/charttable/?cid=43906

${ }^{136}$ Ellen Schloemer et al, "Losing Ground: Foreclosures in the Subprime Market and Their Cost to Homeowners" (December 2006), www.responsiblelending.org.

137 "Losing Homes and Neighborhoods," NY Times editorial, April 10, 2007.

${ }^{138}$ Vikas Bajaj, "Slumping Confidence in Bonds Tied to Subprime Mortgages," NY Times, June 16, 2007.

139 "Losing Homes and Neighborhoods," NY Times editorial, April 10, 2007.

${ }^{140}$ Vikas Bajaj, "Effort to Advise on Risky Loans Runs into Snag," NY Times, June 12, 2007.
} 
captured through "reverse redlining" and aggressive sales tactics. A 2005 Federal

Reserve study found that, regardless of income, African-Americans were three times as likely as whites to be charged excessively high rates. ${ }^{141}$ The simplest way to prevent predatory lending is to require housing counseling by an independent non-profit agency before a high-cost, subprime loan can be made. ${ }^{142}$

The State and local authorities should also stop providing economic development subsidies to subprime lenders. HSBC has been one of the dominant subprime lenders since it acquired scandal-plagued Household International in 2002-2003 for \$14 billion. ${ }^{143}$ According to a new report, 63\% of HSBC's mortgages in 2006 were subprime, including 6,295 loans with rates at least eight percentage points over the Treasury level. ${ }^{144}$ In 2006 HSBC received $\$ 79$ million in tax breaks from the Amherst IDA to expand a data center, a sum "equal to $\$ 6.6$ million for each job to be created."145 HSBC then received a massive array of IDA, Empire Zone, and Power Authority subsidies for a new data center in Cambria that will employ only 78 people, of which 56 will be new hires. ${ }^{146}$ Apart from the fact that neither Amherst nor Cambria are distressed areas, and the fact that the huge subsidies created so few jobs, why should the government be subsidizing an industry that has proven so irresponsible and destructive?

\footnotetext{
141 "Mayor Bloomberg Announces Innovative Initiative to Combat Predatory Lending and Prevent Mortgage Foreclosures," October 18, 2005 Press Release, available at http://www.banking.state.ny.us/pr051018.htm

${ }^{142}$ For a model predatory lending statute with this and other protections, see "Progressive Agenda for State Housing Policy 2007." For recent legislation, see Minnesota's predatory lending bills, HF931/SF988 and HF1004/SF809, passed in May 2007.

${ }^{143}$ See "Fair Finance Watch: ICP Campaigns, HSBC" at http://www.fairfinancewatch.org/campaign.html.

144 Jonathan D. Epstein, “Disparities found in loan rates to minorities," Buffalo News, June 5, 2007.

${ }^{145}$ David Robinson, "HSBC granted \$79 million in tax breaks by Amherst IDA," Buffalo News, November 18, 2006.

${ }^{146}$ Thomas J. Prohaska, “Bank center OK'd for Cambria,” Buffalo News, March 16, 2007.
} 
The City of Buffalo should also consider stronger measures to combat predatory lending. The City of New York has a $\$ 1.35$ million initiative called PACE ("Preserve Assets and Community Equity") that includes outreach, education, financial assistance, and legal strategies for residents of neighborhoods that have experienced high rates of predatory lending. While Buffalo lacks the resources to mount such a large initiative, it should consider, at the very least, using its "bully pulpit" and media access to educate the public and to denounce exploitative practices.

Another lending practice in need of reform is the "partial foreclosure." When borrowers fall behind on payments, many lenders initiate foreclosure actions and evict the homeowner, only to decide that it is not worth it to complete the foreclosure and take title to the property. As a result, the property is abandoned and left in limbo; often with the owner unaware that he still owns the property. The State of New York is itself guilty of such practices. It purchased the tax liens on 1,500 Buffalo properties and then turned them over to a for-profit company which failed to foreclose on them and return them to productive use. The first step the State should take in addressing Buffalo's housing crisis is to take responsibility for these 1,500 blighted properties and provide the funding necessary to rehab or dismantle them. ${ }^{147}$ The State should also pass legislation preventing private lenders from undertaking "partial foreclosures" without assuming responsibility for properties.

The State should also consider tougher laws and more law enforcement resources devoted to "flipping:" the practice of buying a home and re-selling it quickly at an inflated price, often in collusion with an appraiser, real estate agent, mortgage broker, or title company. "Flippers" often defraud not only the buyer but also the lender, or the

${ }^{147}$ Mark Sommer, “Derelict Properties in Limbo,” Buffalo News, February 28, 2007. 
eventual holder of the mortgage. ${ }^{148}$ By saddling unsuspecting buyers with houses they cannot afford to maintain, flipping increases unaffordability and leads to further abandonment.

In Buffalo, the Mayor's Anti-Flipping Task Force has conducted extensive research and developed a wide array of legislative and policy recommendations to reduce flipping, including:

- change City policy to allow owners to pay their property taxes in four installments, as is allowed by other towns and villages in Erie County, to reduce the number of tax foreclosures;

- $\quad$ enact a Third Party Transfer ordinance modeled after New York City's, which would allow the City to transfer distressed properties to third parties required to rehabilitate them, instead of offering them at auction;

- alter state Real Property Tax Law $§ 1136$ to allow a "pre-auction" of taxforeclosure properties to owner-occupants. Current law requires that the properties be sold to the highest bidder. ${ }^{149}$

In an encouraging development, Attorney General Andrew Cuomo recently announced the first major lawsuit regarding flipping in Buffalo, accusing East Coast Capital of defrauding its victims of over $\$ 2$ million in a scam involving 53 houses. ${ }^{150}$ More such enforcement actions and reform legislation will help preserve the City's housing stock and protect its residents from impoverishment.

Another reason for housing abandonment is the failure of absentee landlords to make necessary repairs. When housing values are falling in a neighborhood, many landlords refuse to invest money in repairs, with the result that the City eventually condemns it or the landlord simply walks away from it when it become uninhabitable. One way to

\footnotetext{
148 “Mayor's Anti-Flipping Task Force: First Year Report,” p. 12, available at www.buffaloflipping.com ${ }^{149}$ Id., pp. 25-27.

${ }^{150}$ Phil Fairbanks, "Cuomo suit alleges plan to defraud investors in 'house flipping' scam, Buffalo News, May 24, 2007.
} 
prevent neglect is to give tenants and cities better legal tools to force landlords to make repairs. The current law in New York forces tenants seeking repairs to risk eviction by withholding rent. The State should pass legislation modeled on Minnesota's Tenant Remedies Act, which allows tenants and city attorneys to sue landlords in simple and fast court procedures to obtain repairs and avert condemnations. ${ }^{151}$

The City of Buffalo should also study New York City's efforts to address this issue with a local law. New York City recently passed a Safe Housing Act which requires the Department of Housing Preservation and Development to identify 200 buildings each year with the worst histories of emergency repairs and uncorrected code violations and force their landlords to make repairs. If they refuse, the department will make the repairs itself and bill the landlords. ${ }^{152}$

In its funding for affordable housing, the State should prioritize rehabilitation of existing units over construction of new units. In its point systems for Low Income Housing Tax Credits and other State programs, the State should dramatically increase the points given for rehabbing existing housing instead of building new: both to minimize the environmental damage caused by new construction and to encourage the revitalization of urban cores. A particularly high priority should be those abandoned housing units that are still amenable to rehabilitation rather than demolition.

Similarly, in its home-ownership programs, the State should focus less resources on creating first time homebuyers and more resources on protecting existing homeowners

\footnotetext{
${ }^{151}$ Minn. Stat. 504B.381 et seq.

152 Ray Rivera, “Council Passes Bill Enabling City to Fix Worst Buildings” New York Times, May 31, 2007
} 
from foreclosure and helping them to keep their houses in good repair. It is much cheaper and more efficient to keep existing homeowners solvent than to replace them.

The City of Buffalo can also act to preserve its affordable housing stock. First, it can devote more of its CDBG and HOME dollars to the preservation and rehabilitation of affordable rental housing. In the 2007-2008 Action Plan, for example, it appears that no CDBG dollars, and only \$1.6 million in HOME funds, are devoted to the rehabilitation of rental housing. In addition to the remarkably high amounts for "administration and planning" and "program delivery," the City puts too much money into homeownership subsidies and the new construction of single-family homes. As a result, the residents who most need affordable housing - very low income renters at risk of homelessness - get little benefit from the City's CDBG and HOME spending. According to HUD, in 20052006 , only $0.07 \%$ of the beneficiaries of the City's CDBG spending were extremely low income. ${ }^{153}$ The City should prioritize the preservation and greening of the affordable rental housing that serves the residents most at risk of homelessness.

Housing abandonment is also exacerbated by the cumbersome process the City must follow to foreclose and dispose of tax-delinquent properties. New York State should examine best practices from other states for legislation that would enable the City to more quickly transfer abandoned properties to responsible new owners. Buffalo should consider extending its Urban Homesteading program, in which the City takes title to properties, cleans the tax liens, and then sells properties for a dollar. It may be that the City would realize more revenue by quickly returning the properties to productive use

\footnotetext{
${ }^{153}$ Community Development Block Grant Performance Profile, Buffalo, New York, available at http://www.hud.gov/offices/cpd/communitydevelopment/library/performanceprofiles/ny/05 BuffaloNy.xls. HUD defines extremely low income as earning less than $30 \%$ of the region's median income.
} 
than by allowing them to deteriorate further while waiting for buyers willing to pay off the liens.

Buffalo should examine the experiences of cities such as Flint, Atlanta, St. Louis, Louisville, and Cleveland, which have used land-banking to preserve and recycle abandoned housing more efficiently. A land bank is a "governmental entity that focuses on the conversion of vacant, abandoned, and tax-delinquent properties into productive use."154 The Genesee County Land Bank in Flint, considered a national model, has title to over 4,000 properties; it "assembles land for transfer to adjacent homeowners, develops long and short-term green spaces, and assembles land for new housing and commercial development." ${ }^{, 155}$ Interestingly, the Genesee County Land Bank also runs a foreclosure prevention project in conjunction with the County Treasurer, which allows the treasurer to postpone foreclosure for a home owner facing a "substantial financial hardship. $" 156$

\section{iv. Deconstruction and Recycling}

When deciding whether to rehab or dismantle a housing unit, the City should consider not only the up-front costs of rehab versus demolition, but also the environmental costs and benefits. But, even after this more thorough analysis, many of the roughly 9,000 abandoned structures will be removed. The question then becomes how to remove them in a cost-effective way that promotes the City's affordable housing and environmental goals.

\footnotetext{
${ }^{154}$ Frank S. Alexander, "Land Bank Authorities: a Guide for the Creation and Operation of Local Land Banks," Local Initiatives Support Coalition (2005), available at www.lisc.org/resources. See also Todd Chard, "Land Banking in Buffalo," available from the author.

$155 \mathrm{http}: / /$ www.thelandbank.org/aboutus.asp

${ }^{156} \mathrm{Id}$.
} 
The first priority is to remove structures as quickly as possible. Abandoned buildings impose high costs: fires, criminal activity, maintenance costs, and lost property tax revenue (including the negative effect on the property values, and hence property tax revenues, of nearby properties). Abandoned buildings cause a vicious spiral: because they lower neighborhood property values, they increase the number of cases in which an owner's liabilities, such as taxes and mortgages, outweigh the property's value, creating a large incentive to abandon. ${ }^{157}$

Given these costs, it is worth asking, for example, whether the City gains more by hiring an additional police officer or by removing more abandoned houses. Given the City's financial distress, it is also worth asking whether the State should provide enough funding to remove all the unsalvageable buildings in Buffalo within one year, rather than allowing them to sit vacant for five to ten years as the City attempts to catch up. A larger up-front investment could save the taxpayers millions of dollars over time.

How should the unsalvageable buildings be removed? Deconstruction is the "process of carefully dismantling a building in order to salvage components for reuse and recycling." $" 158$ Deconstruction is more environmentally friendly than demolition because it creates less airborne pollutants, ${ }^{159}$ less landfill waste, and less vehicular pollution (trucking the waste to the landfill). By re-using materials, deconstruction reduces the pollution caused by the extraction, transport, and processing of raw materials.

Deconstruction also has economic development benefits because it is more labor-

\footnotetext{
${ }^{157}$ Benjamin P. Scafidi et al, “An Economic Analysis of Housing Abandonment,” Journal of Housing Economics, Vol. 7, No. 4 (December 1998)

158 “Salvaging Yesterday's Buildings for Tomorrow's Sustainable Communities," Institute for Local SelfReliance (1999). www.ilsr.org.

${ }^{159}$ See Peter Scheff, "Demolition of high-rise public housing increases particulate matter air pollution in communities of high-risk asthmatics," Journal of Air and Waste Management Association (2006).
} 
intensive than demolition. Despite higher labor costs, deconstruction stays costcompetitive because it avoids land-fill fees and generates revenue through re-sale of materials. ${ }^{160}$ Deconstruction may also further housing affordability by making salvaged materials available at a low cost.

Deconstruction is a technique well-suited to Buffalo because it works best on Buffalo's most typical housing stock: "smaller wood or timber-framed structures," “especially housing stock built before World War II."161 In Buffalo, 58\% of the housing units (and probably a much higher percentage of abandoned units) were built before $1940 .^{162}$

Deconstruction has the potential to be a cost-competitive alternative to demolition, even without factoring in the environmental and economic development benefits. In a study of six deconstructions in Florida, the net deconstruction cost averaged $37 \%$ less than demolition would have cost. ${ }^{163}$ The costs varied greatly from house to house, depending on the condition of the house and the value of the salvageable materials. $^{164}$

A new non-profit, Buffalo ReUse, has won a \$200,000 research and development grant from the State and recently deconstructed its first house. ${ }^{165}$ The State should continue to fund the expansion of this industry and should also examine some of the policy issues raised by demolition and deconstruction. For example, do current tipping

\footnotetext{
${ }^{160}$ See Erik Faleski, "Deconstruction: Policy Alternatives for Buffalo," and Sean Cooney, " Residential Deconstruction in Buffalo: a Viable Alternative to Demolition," both available at http://green-housingbuffalo.wikispaces.com.

161 "Demolition ... The First Step of Reconstruction," National Demolition Association (1999), www.demolitionassociation.com.

${ }_{162}$ Comprehensive Plan, part 1.4.3

${ }^{163}$ B. Guy, "Building Deconstruction: Reuse and Recycling of Building Materials." Center for Construction and Environment (2000), cited in Cooney, p. 8.

${ }^{164}$ See also "A Report on the Feasibility of Deconstruction," NAHB Research Center (2001).

$165 \mathrm{http}: / /$ www.buffaloreuse.org/
} 
fees at landfills adequately reflect the environmental and social costs of demolishing and throwing out building materials in landfills? Tipping fees at landfills in the Buffalo area range from $\$ 30$ to $\$ 50$, while for the state as a whole they average $\$ 67.74 .^{166}$ An added environmental impact fee for the disposal of building materials would create an incentive to deconstruct and recycle; the fee proceeds could be used for deconstruction grants or other environmental measures. The State should also explore changing building codes and other regulations that make it difficult to re-use salvaged lumber because it is not "stamped" and graded. There may be ways to facilitate re-use for certain purposes without compromising safety and quality.

The City can also encourage deconstruction by working with Buffalo ReUse to develop a sophisticated cost/benefit analysis to determine how much, if any, deconstruction it should require for a given building. That analysis should include:

- The environmental costs of air pollution from the demolition process and transport to the landfill, and the air, water, and soil pollution caused by placement of materials in landfills;

- The environmental benefits of salvaging building materials instead of extracting, processing, and transporting new materials;

- The affordable housing benefits of generating inexpensive, recycled building materials;

- The increased number of jobs deconstruction creates.

\section{v. Vacant Lots and Brownfields}

Buffalo had 10,170 vacant residential lots in 2000; it has more now, and the number will continue to grow for the foreseeable future (the City's Comprehensive Plan estimates that the population, currently 292,000 , will dip to 250,000 before it returns to

\footnotetext{
${ }^{166}$ Faleski, pp. 9, 14.
} 
current levels around 2025). ${ }^{167}$ Some of these lots should be used for housing, but many should be dedicated to other uses that are environmentally friendly and help revitalize distressed neighborhoods. ${ }^{168}$

Green uses for vacant lots can complement the City's affordable housing policy by providing low-income residents with opportunities for recreation and access to fresh, affordable produce. Also, reclaiming these lots for productive uses will help to stabilize neighborhoods and property values and prevent further abandonment. The Philadelphia Green program has documented that merely cleaning and greening a vacant lot adds $30 \%$ to the fair market value of the adjacent properties. ${ }^{169}$

In developing a coherent land use policy for its vacant lots, the City should build on existing efforts. The Local Initiatives Support Corporation - Buffalo (LISC) is leading a vacant properties initiative based on Blueprint Buffalo, a 2006 report from the National Vacant Properties Campaign. ${ }^{170}$ LISC has assembled committees to address the four strategies recommended by the Blueprint: (i) a regional real property information system; (ii) comprehensive code enforcement, (iii) right-sizing and greening the city; and (iv) greyfields and brownfields redevelopment.

LISC is also providing research and expertise on land-banking models such as those of Genesee County, Michigan, which, in addition to helping preserve existing structures, can facilitate the quick, strategic, and comprehensive re-use of vacant lots. Various changes in state legislation can enable land-banking to flourish. For example,

\footnotetext{
${ }^{167}$ Comprehensive Plan, p. 9.

${ }^{168}$ See Lauren Weiss, "Environmentally Friendly Uses for Vacant Properties in Buffalo," http://greenhousing-buffalo.wikispaces.com.

${ }^{169}$ See "Pennsylvania Horticultural Society Issue Brief," available at www.pennsylvaniahorticulturalsociety.org/phlgreen/issuebrief.pdf, and Blueprint Buffalo at p. 27, citing Susan Wachter, "The Determinants of Neighborhood Transformation in Philadelphia" (2005)

${ }^{170}$ Available at www.vacantproperties.org.
} 
Michigan makes it easier to recycle vacant residential lots by qualifying them as brownfields and providing access to brownfield redevelopment funding.

Buffalo has a variety of successful programs already. Grassroots Gardens of Buffalo helps people "create and sustain community gardens on city-owned vacant properties throughout Buffalo." These ornamental, produce and mixed-use gardens, "help beautify and strengthen the neighborhoods around them while providing fresh fruit and vegetables to many city residents." ${ }^{\prime 11}$ Founded in 1995, Grassroots now includes over 40 gardens.

East side activist Rosa Gibson and her colleagues have turned 12 vacant lots into flower and vegetable gardens and a toddlers' playground at Wohlers Avenue and Northampton Street. Neighborhood volunteers and people sentenced to community service tend the gardens. Design students from the University at Buffalo helped to design a unique "shoe garden;" and there is also a memorial garden for those who have lost loved ones. ${ }^{172}$

Still in the planning stages is a proposed Queen City Farm project to reclaim a mostly abandoned 2.5 acre section in east Buffalo bounded by East Utica, Purdy, Masten, and Glenwood avenues. The project coordinator, Rod McCallum, is seeking grants to restore the currently derelict Engel House at 194 E. Utica, once a grand mansion, which had been targeted for demolition until city officials were persuaded to save it. ${ }^{173}$

\footnotetext{
${ }^{171} \mathrm{http}: / /$ www.grassrootsgardens.org/

${ }^{172}$ Michael J. Billoni, “Gibson's gardens brighten the East Side,” Buffalo News, June 10, 2007, and "Five Questions for Rosa Gibson," ArtVoice volume 6, number 8.

${ }^{173}$ Harold McNeill, "Urban farm project for East Side area energizes coalition,” Buffalo News, May 22, 2007.
} 
On the city's west side, the Massachusetts Avenue Project (MAP) has assembled an urban farm on seven adjacent vacant lots. ${ }^{174}$ MAP's Growing Green program uses the farm to teach disadvantaged young people farming, nutrition, and business training.

Urban farms and gardens such as MAP's fight pollution not only by adding plant material that absorbs pollutants but also by providing a local food source. Currently in the U.S., each bite of food we eat travels an average of over 1500 miles to reach us, generating a huge amount of vehicular pollution. ${ }^{175}$

Many other cities have programs of interest. The Philadelphia Green program, operated by the Pennsylvania Horticultural Society in conjunction with the City of Philadelphia, is perhaps the national model for vacant lot management. Buffalo should look at what other cities have done and develop an inventory of exiting lots, a menu of options for their re-use, and a set of guidelines to help determine which is the best option for each individual lot. The City should then work with neighborhood groups and nonprofits to re-use the lots.

Planting trees in vacant lots can have many benefits. Even before the October 2006 storm, Buffalo was lacking in trees. The City had 20,000 trees in parks and 65,000 along streets, ${ }^{176}$ resulting in a $12 \%$ tree canopy, which compares to a national average of $30 \%$ tree canopy and a recommended level of $40 \% .{ }^{177}$ Trees are vital in reducing air pollution and controlling storm water. Buffalo's trees remove 335,000 pounds of pollutants from the air each year, a service valued at approximately $\$ 826,000 .^{178}$ They

\footnotetext{
${ }^{174} \mathrm{http}: / /$ www.mass-ave.org/

${ }^{175}$ The distance our food travels has risen $25 \%$ since $1980.90 \%$ of all fresh vegetables eaten in the U.S. are grown in the San Joaquin Valley of California. Diana Deumling et al, "Eating Up the Earth," available at www.RedefiningProgress.org. See also Bill McKibben, Deep Economy, p. 47 (Henry Holt, 2007)

${ }_{176}$ Id., p. 47

177 "Urban Ecosystem Analysis: Buffalo-Lackawana Area," American Forests (2003), p. 3, p. 6

${ }^{178}$ Id., p. 3.
} 
also provide storm water control value of $\$ 34,286,526$ (the amount of money it would take to build storm water facilities to process the water that the trees currently retain). ${ }^{179}$ And they store 133,878 tons of carbon and sequester 1,042 tons of carbon per year. ${ }^{180}$

In addition to gardens, farms, and trees, green uses may include:

- Storm water retention ponds, wetlands, swales and rain gardens to help reduce sewer overflows;

- Native wildflower plantings;

- Greenways: linking vacant lots and other properties together to create new walking and biking paths through the City;

- Pocket parks, playgrounds, and sculpture parks;

- Solar power sites;

- Wind farms.

Of particular concern are the city's 56 identified brownfields. As the City's Comprehensive Plan states, "More rapid assembly and clean-up of brownfield sites is urgently needed to support the City's and region's economic development program." "181 One simple way to begin brownfield clean-up is phytoremediation: the process by which plants such as sunflowers, poplar trees, Indian mustard, alpine pennycress can be used to absorb chemicals such as lead, arsenic, zinc, and DNT. ${ }^{182}$

Stephen Banko, the head of the local HUD office, has criticized the City for failing to seek funds more aggressively from HUD’s Brownfields Economic

\footnotetext{
${ }^{179} \mathrm{Id}$.

${ }^{180} \mathrm{Id}$.

${ }^{181}$ Comprehensive Plan, p. 16.

${ }^{182}$ Weiss, p. 12, citing Using Vegetation to Enhance in situ Bioremediation, Erikson et al, and Phytoextraction of Metals from Contaminated Soil, M.M. Lasat, Journal of Hazardous Substance Research (2000).
} 
Development Initiative to redevelop its brownfields. ${ }^{183}$ The City of Lackawana recently saw an old steel plant brownfield - a federal superfund site - become the Steel Winds wind farm, with eight turbines producing enough clean energy for 7,000 homes. As Mayor Norman L. Polanski, Jr., once a laid-off steel worker, said, "It's changing the image of the city of Lackawana. We were the old Rust Belt, with all the negatives. Right now, we are progressive, and we are leading the way on the waterfront." 184 Perhaps Buffalo can also find pioneering green uses for some of its brownfields and seek federal and state funding to make them a reality.

Other cities have witnessed visionary projects that transform brownfields and vacant parcels with a combination of affordable housing and urban farming. Examples worth studying include Troy Gardens in Madison, ReVision House Urban Farm in Dorchester, and, still under development, Via Verde in the Bronx. ${ }^{185}$ Via Verde will include low- and moderate-income housing bound together by courtyards and roof gardens to be used for everything from harvesting rainwater to growing vegetables and fruit. It will feature an outdoor amphitheater, apartments designed for breezes, a fitness center, wiring for Internet access, "live-work units" for people who work at home, stoops with photovoltaic canopies, and even a Christmas tree farm. ${ }^{186}$

\section{f. Making New Housing Units Greener}

When the State, City, and non-profits create new affordable housing units, green strategies and considerations should inform every stage of the development process.

\footnotetext{
${ }^{183}$ Peter. Koch, "Like Finding Money on the Street," ArtVoice volume 5, no. 2.

${ }^{184}$ David Staba, “An Old Steel Mill Retools to Produce Clean Energy,” NY Times, May 21, 2007.

185 See www.troygardens.org and www.vpi.org/Re-VisionFarm

${ }^{186}$ www.plannyc.org/project-106-Via-Verde---New-Housing-New-York-Legacy-Project
} 


\section{i. Rehab versus New Build}

The first question in creating housing units is whether to build new structures or renovate existing, unused structures such as abandoned homes or industrial buildings. In making the cost-benefit analysis of the choice between new and rehab, decision-makers should consider factors such as:

- The environmental costs of using new materials;

- The environmental costs of demolishing old housing;

- The unique and appealing architectural character of Buffalo's older houses and buildings.

Artspace and Belmont Shelter have provided a good example of rehab with their "Artists Lofts" affordable housing project. By preserving and renovating an old factory building on Main Street, this project both benefits the environment and preserves history. ${ }^{187}$

Buffalo's Habitat for Humanity chapter has wisely prioritized rehab, doing about three times as many rehabs as new-builds each year. ${ }^{188}$ But is an interesting question whether Habitat should do any new construction, given the large number of abandoned homes in Buffalo and the environmental benefits of re-using them. When the Buffalo Municipal Housing Authority created a large number of infill units to replace units in its Lakeview Homes development, it looked at existing units but did not find it cost-effective to rehab them. If the environmental costs and benefits had been factored into the equation, however, the decision might have been different.

\footnotetext{
${ }^{187}$ Mark Sommer, "Success in Pittsburgh puts Buffalo in picture,” Buffalo News, March 10, 2007.

${ }^{188}$ Martha R. McNeill, "Buffalo Habitat for Humanity: the Challenges and Prospects of Green Building," p. 8, http://green-housing-buffalo.wikispaces.com.
} 


\section{ii. Location}

The location of affordable housing poses a policy dilemma. Environmentally speaking, all new housing should be developed in the city, to reduce vehicular traffic, limit habitat loss, and make the most efficient use of existing buildings and infrastructure. However, because people with low incomes, particularly people of color, have been excluded from the suburbs, equal justice suggests locating more affordable housing in the suburbs. If Buffalo is to overcome its status as the eighth most segregated metropolitan region in the country, some dispersal of affordable housing seems necessary.

One thing is clear for both environmental and affordability reasons: affordable housing (like all housing) should be located near mass transit, and, wherever possible, in neighborhoods where one can walk and bike to nearby amenities such as parks, playgrounds, schools, and shops. According to the 2000 census, $31.4 \%$ of the households in Buffalo have no vehicles available. In other words, most of the people who need affordable housing also need accessible mass transit.

\section{iii. Density}

The question of density can also create conflict between policy goals. Environmentally, denser housing is much preferable. A 30-unit high-rise is more green than 30 single family homes, because it uses less raw materials, less land, and less energy. However, densely aggregating housing for people with low incomes leads to ghettoization. Given our current levels of economic and racial segregation, large-scale, dense affordable housing can be disastrous. One way to resolve these factors is to 
promote density in upper, moderate, and mixed income housing, while promoting a dispersal (along mass transit routes) of affordable housing. The more successfully the region creates mixed income developments and neighborhoods, the more freely it can promote density.

\section{iv. Size}

The size of American houses makes them more expensive and more polluting. Between 1975 and 2000 new U.S. homes grew nearly 38 percent, to reach an average of 2,265 square feet - twice the size of typical homes in Europe or Japan and 26 times the living space of the average person in Africa. Larger homes use more materials; they also require more energy to operate, maintain, and demolish. They also encourage bigger and more appliances. Home appliances are the world's fastest-growing energy consumers after automobiles; they cause 30 percent of industrial countries' electricity consumption and 12 percent of their greenhouse gas emissions. ${ }^{189}$

One factor that drives up house sizes is the competition among suburbs to lure wealthy residents and exclude residents with low incomes, who pay less taxes and need more services. When suburbs require large lots, the only way developers can turn a profit is to build large, expensive houses on them. According to local developers, for example, the suburb of Clarence requires such large lots that developing a home priced under $\$ 300,000$ is not feasible. ${ }^{190}$ While small and medium-sized houses often "age into" affordability, larger houses never become affordable, even later in their life-cycle, unless

\footnotetext{
${ }^{189}$ WorldWatch Institute, "Making Better Energy Choices," http://www.worldwatch.org/node/808

190 Sandra Tan, "These 'burbs take big bucks," Buffalo News, February 25, 2007
} 
they are carved up. State action to limit sprawl and combat exclusionary zoning can create denser, smaller, more environmentally sound housing.

In the wake of Hurricane Katrina, affordable housing advocates are also rethinking the issue of size. For years, American zoning and building codes and customs have made a certain minimum size an aspect of "decent" housing. But what if it is possible to build attractive, durable housing at a greatly reduced price by making it smaller? Tim Maloney, a Kentucky architect, has designed a compact eco-home that costs \$40,000. ${ }^{191}$ "Katrina Cottages" (designed to be no more expensive than the FEMA trailers used for refugees from Hurricane Katrina) offer another example of small but high quality housing. ${ }^{192}$ These and related designs - many incorporating modular, prefabricated elements - may be an excellent way to do infill housing in Buffalo. Very small houses for low-income homeowners could succeed in the difficult task of stabilizing areas dominated by absentee landlords without pricing out current residents. Smaller houses can also help bring homeownership to people with low incomes and to people of color, who are disproportionately renters.

Small houses may make sense for the young singles, childless couples, single parents, and seniors who make up the majority of Buffalo residents. The average household size in Buffalo is only 2.29 persons. Of homeowners, 39.2\% are living alone, and $29.7 \%$ are living with one other person. Overcrowding is a relatively minor problem in Buffalo, with only $3.2 \%$ of our housing units overcrowded. ${ }^{193}$ Bearing these facts in mind, funders and developers should consider smaller housing units, and the State and City should modify housing and zoning codes as necessary to allow for them.

\footnotetext{
191 “Affordable by Design,” Alice Horrigan, www.emagazine.com

192 www.katrinacottages.com.

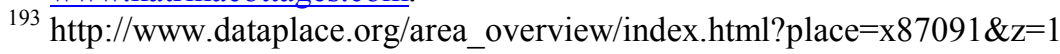




\section{v. Materials}

One of the main ways housing pollutes is through its use of materials. Building and construction activities consume 3 billion tons, or $40 \%$, of the raw materials used each year. ${ }^{194}$ Affordable housing policy should reward the use of materials that cause the least environmental damage as they are harvested, processed, and transported to their destinations. ${ }^{195}$ Reused or recycled materials cause less damage than new materials. Local materials cause less damage than materials from far away. Materials that quickly replenish themselves - like straw - cause less damage than materials that take a long time to regrow, like hardwoods. In Buffalo, straw bale construction was used recently to make a greenhouse building for the Massachusetts Avenue Project. ${ }^{196}$ It could be used for housing, as it is in other parts of the country. ${ }^{197}$ For flooring materials, greener choices include bamboo, wool carpet, linoleum, and carpet made from recycled plastic bottles. ${ }^{198}$ For roofing, shingles made from recycled plastic and wood are now available.

The more durable the material, the less environmental damage will be done in maintaining and replacing it. Fiber-cement siding, for example, lasts longer, rots less, and reduces the need for repainting. ${ }^{199}$ Another durable building material is of concrete

\footnotetext{
${ }^{194}$ D.M. Roodman and N. Lenssen, A Building Revolution: How Ecology and Health Concerns are Transforming Construction, Worldwatch Paper 124, Worldwatch Institute, Washington, D.C., March 1995 , p. 5 .

${ }^{195}$ For free software that can be used to analyze the "greenness" of various building material choices over the life cycle of a building, see http://www.bfrl.nist.gov/oae/software/bees.html.

${ }^{196}$ Lou Michel, "Straw house built to stand," Buffalo News, April 23, 2007.

${ }^{197} \mathrm{http}$ ://www.greenhomebuilding.com/strawbale.htm

${ }^{198}$ See Dennis Andjejko, "West Side Community: Sustainable Products and Materials Pallete," December 2001

199 “Top 15 Green Building Ideas,” Green Affordable Housing Coalition Fact Sheet No. 12
} 
made with 30 to $50 \%$ flyash, which is a byproduct of coal burning plants. Incorporating flyash also reduces the mining and energy consumption needed to make the concrete. ${ }^{200}$

Even the most durable homes will be dismantled someday. An important environmental question about materials is how easy to re-use and recycle they are. This question goes not only to the nature of the material but also to how materials are joined together in the building process. The easier it is to separate out the salvageable materials, the less environmental harm will be done.

Green design has always focused not just on the health of the planet but also on the health of residents and neighbors. Here, as elsewhere, green design complements, rather than contradicts, the goal of providing safe, decent, and affordable housing. Affordable housing is not safe and decent (or even affordable) if it aggravates asthma and increases cancer incidence by using toxic paints and wood with toxic chemicals such as formaldehyde. State and local policies should require, or at least reward, the use of nontoxic paints, wood products, and floorings.

In Seattle, the county health department and the public housing authority collaborated on a set of "Breathe Easy Homes" to replace a dilapidated housing project where over $10 \%$ of the residents suffered from asthma. The new development is "a handsome, mixed-income community spread over 34 city blocks: green, sustainable, walkable, with expansive parks and majestic old trees, capacious front porches to deter crime, and a street grid connected to the rest of funky West Seattle." ${ }^{201}$ It includes 35 townhouses specifically designed to reduce asthma triggers with

- moisture-proof foundations to keep mold out,

\footnotetext{
200 "Top 20 No or Low-Cost Green Building Strategies," http://globalgreen.org/greenbuilding/GAHI_top20.html.

${ }^{201}$ Madeline Drexler, "The People's Epidemiologists," Harvard Magazine, March-April 2006.
} 
- non-toxic paints,

- cabinets without formaldehyde,

- high-quality ventilation systems,

- hardwood floors in place of carpeting,

- mattress covers to prevent dust mites, and

- $\quad$ special cleaning supplies including high-efficiency vacuum cleaners. ${ }^{202}$

The Buffalo Niagara Medical Campus (BNMC) is one of the city's biggest economic redevelopment success stories. The BNMC, which includes facilities of Kaleida Health, Roswell Park, the University at Buffalo, and others, has over 8,000 employees, sees nearly half a million patients per year, and has generated roughly $\$ 400$ million in research grants in the past five years. With its 100-acre campus, The BNMC has helped to spur the renaissance of the nearby Allentown and Downtown neighborhoods. But also adjacent to the BNMC is the Fruit Belt, a ninety-percent African-American community where $44.7 \%$ live below poverty level, $59 \%$ of the households have incomes of less than $\$ 20,000,{ }^{203}$ and $11 \%$ of the children have asthma. ${ }^{204}$

Two of the guiding principles in the BNMC master plan are to "improve physical integration between campus and neighborhoods" and to "foster community and economic development.",205 One of the BNMC's four functions is to "support the surrounding neighborhoods." The master plan lists the rehabilitation of Fruit Belt housing stock as one of its priorities. As yet, however, the BNMC has not acted directly to help redevelop the dilapidated, unhealthy housing and the vacant lots immediately adjacent to it in the Fruit Belt.

\footnotetext{
${ }^{202} \mathrm{Id}$.

${ }^{203} 2000$ Census figures; see http://www.daemen.edu/offices/grants/Newsletters/09-05-06.htm

204 "Results of Landmark Study of East Side Community Health Needs," www.kaleidahealth.org/news/archive/0501/052201.asp.

${ }^{205}$ Master Plan available at www.bnmc.org.
} 
Imagine if the BNMC partnered with the Fruit Belt neighborhood to develop a "healthy housing" project. In addition to the indoor air quality measures pioneered by the Breathe Easy Homes, the BNMC could incorporate an urban farm or community gardens like those of Troy Garden, Re-Vision House Urban Farm, or Via Verde. The BNMC could partner with the MAP Growing Green project and others to integrate access to healthy produce and education in gardening, cooking, and nutrition with its housing. The BNMC could draw on the expertise of local scholars such as urban planner Samina Raja, an expert on urban food systems who is already working with the BNMC on a public health initiative, and J.S. Lwebuga-Mukasa, who has studied the prevalence of asthma in Buffalo residents. ${ }^{206}$ The BNMC could collaborate with community partners such as the St. John Baptist Church, which is planning to build nearly 150 new homes in the Fruit Belt in the next few years. ${ }^{207}$ Imagine what an emblem of revitalization it would be if the BNMC helped bring fruit trees back to the Fruit Belt. ${ }^{208}$

\section{vi. Energy}

The worst "housing pollution" comes from the energy used in heating, cooling, lighting, and powering appliances. And perhaps the single easiest way to make housing more affordable for people with low incomes is to lower their utility bills (or, if the landlord pays the utility bills, to lower their rent by lowering the landlord's utility bills). According to the Department of Energy, the average energy bill for a home in Buffalo is $\$ 2267$, while the average bill for an energy efficient home would be $\$ 1451$, for a savings

\footnotetext{
${ }^{206}$ See, for example, his article, "Local ecological factors, ultrafine particulate concentrations, and asthma prevalence rates in Buffalo, New York, neighborhoods," available at www.ncbi.nlm.nih.gov/

${ }^{207}$ Michael Spong, "Fruit Belt renewal moving ahead," Business First of Buffalo, April 14, 2006.

${ }^{208}$ See Gary A. Wilson, "The Fruits of New Life: The Prospects of Green Affordable Housing in the Fruitbelt," available from the author.
} 
of $\$ 816 .{ }^{209}$ To give an example, the DOE estimates that simply adding basement insulation to a home in Buffalo will save the resident $\$ 390$ per year in heating bills. ${ }^{210}$

Funders and developers of affordable housing in Buffalo should focus intently on reducing energy use and incorporating green energy sources through techniques such as insulation, daylighting, passive solar heating, high efficiency furnaces/boilers and appliances, compact fluorescent and LED lighting, solar power, and solar hot water heating. Buffalo has LEED-certified architects, engineers, and other professionals who can implement these strategies, if their clients request it. $^{211}$

One very promising technique, particularly for larger projects, is geothermal heating/cooling. Geothermal systems take advantage of the fact that beneath the earth's surface water stays at a remarkably consistent temperature of around 50 degrees Fahrenheit. With relatively little energy, which can be generated by wind or solar power, geothermal systems can use this water to heat a building in the winter and cool it in the summer. Geothermal heating/cooling has already been used in Buffalo in the Church project renovated by Righteous Babe Records; it will be used for the first time in an affordable housing project in the 75-unit Villa Maria Senior Living Community currently being developed. ${ }^{212}$

Many energy efficiency measures add to up-front costs, but pay for themselves over time. To give a few examples, a solar hot water heater has an average installed cost of $\$ 2,500$, but it saves $\$ 303$ per year, and thus pays for itself in 7.4 years. ${ }^{213}$ The payback

\footnotetext{
${ }^{209}$ DOE Home Energy Saver, http://hes3.lbl.gov/hes/hes.taf?f=top

${ }^{210}$ www.eere.energy.gov/consumer/your_home/insulation_airsealing/index.cfm/mytopic $=11470$

${ }^{211}$ For a listing of LEED-certified professionals, see www.usgbc.org/myUSGBC/Members/MembersDirectory.

$\frac{}{212}$ Sharon Lindstedt, "Villa Maria to be converted to senior housing complex," Buffalo News, February 9 , 2006

${ }^{213}$ Rocky Mountain Institute, Home Energy Brief \#5, available at www.rmi.org
} 
period for adding insulation to a home is typically about five years. ${ }^{214}$ An Energy Star clothes washer uses 50 percent less water and 70 percent less energy per load, saving up to $\$ 100$ every year. ${ }^{215}$

Even some of the more expensive items are actually cheaper than conventional alternatives in the long run. For example, the average payback for converting to solar power is 14 years. ${ }^{216}$ That is a long time, but much shorter than the life of the solar power system. And while a solar system in New York may cost roughly $\$ 17,000$ to install, New York State will pay $40 \%$ to $70 \%$ of the cost and help finance the remainder through the New York Energy Smart Loan Fund. ${ }^{217}$ Even green roofs pay for themselves over their lifetime. Although they cost between $\$ 6.40$ and $\$ 15.30$ per square foot to install, as compared to between $\$ 4.00$ and $\$ 6.00$ per square foot for traditional roofing, they last two to three times as long and yield energy savings as well. ${ }^{218}$

The Habitat for Humanity affiliate in Greene County, Pennsylvania took a close look at energy costs in homes they were remodeling and reduced the gas bills for heat and hot water from between $\$ 60$ and $\$ 110$ per month to around $\$ 30$. An Atlanta community found that increasing energy efficiency of new homes added less than $\$ 500$ to construction costs but saved $\$ 400$ per year in energy costs. ${ }^{219}$ As Walter Simpson puts it concisely, "Green buildings cost less, not more."220 That is how Simpson and his colleagues have saved the University at Buffalo over $\$ 9$ million per year in energy costs

\footnotetext{
${ }^{214}$ Rocky Mountain Institute, Home Energy Brief \#1, available at www.rmi.org

215 Energy Star: Home Improvement Tips, http://energystar.gov/index.cfm?c=home improvement.hi tips

${ }^{216}$ Damon Darlin, "Financially, Solar Power for the Home is a Tough Sell," NY Times, April 14, 2007

217 "New York State is Making Solar Electric Energy For Your Home More Affordable Than Ever"

${ }^{218}$ Mike Plumb, "Sustainable Raindrops: Cleaning New York Harbor by Greening the Urban Landscape," pp. 17-18, 36, n. 81, available at http://www.riverkeeper.org/campaign.php/pollution/we_are_doing/986

219 "Energy Efficiency Makes Homes More Affordable," Southface Energy Institute, www.southface.org.

220 Walter Simpson, “A Facitilies Manager's Guide to Green Building Design," http://wings.buffalo.edu/ubgreen/content/programs/greendesign/guide_greendesign.html
} 
through their efforts. That is why the City of Portland concluded that bringing three standard buildings up to LEED levels would produce lifecycle savings of $15 \%{ }^{221}$

For-profit housing developers may continue to focus on first costs, and not lifecycle costs, until a better informed market or government alters their incentives. But for non-profit developers, whose goal is true affordability for their residents, the opportunities to increase energy efficiency already abound.

\section{vii. Water Management}

Greener water for affordable housing means both conserving water and better handling rain water. Conserving water is important for many reasons: it limits damage to natural water sources and leaves more water available for natural uses; it reduces the energy needed to treat the water, pump it to the home, heat it, and then dispose of it properly; and it saves the resident money on water bills. Green design offers many inexpensive ways to conserve water. According to the Rocky Mountain Institute, replacing an old shower head with a water-saving 2.5 gallon-per-minute shower head will cost $\$ 15$, and installing water-efficient faucet heads in kitchen and bathroom sinks will cost $\$ 2$ each; these devices will pay for themselves in less than a year. ${ }^{222}$ When the Buffalo Municipal Housing Authority replaced old water fixtures, it found that water efficient devices would pay for themselves very quickly: 1.6 years for low-flow showerheads, 2.4 years for low-flow toilets, and 1 year for faucet aerators. ${ }^{223}$

\footnotetext{
221 "The Costs and Financial Benefits of Green Buildings," A Report to California's Sustainable Building Task Force," 2003.

222 "Energy Efficiency: First Things First," available at www.rmi.org

${ }^{223}$ Modesto Candelario, Assistant Executive Director BMHA, personal communication,
} 
Doing a better job of managing rain water reduces the need to pump up more fresh water; it reduces the energy needed to treat the rain water that ends up in the sewers; and it reduces the number of sewer overflows. In Buffalo, roughly 68 combined sewer overflows occur each year, sending untreated human, commercial, and industrial waste into the waterways. Storm water pollutants include bacteria, metals, lawn fertilizers and pesticides, automobile oil and grease, toxic chemicals, and trash. Storm water is the second most important pollutant source for the Great Lakes. ${ }^{224}$

Buffalo depends on its waterways for drinking water, recreation, tourism, and many other uses. Lake Erie is a natural resource of world importance: to give just one example, it supports the largest fresh-water fishery in the Great Lakes (an estimated 50 million to 60 million pounds of fish are caught per year). ${ }^{225}$ Buffalo's extensive shoreline along Lake Erie and the Niagara River is one of its greatest assets. Unfortunately, of the 62 "waterbody segments" in the region that were evaluated by the DEC in 2004, 35 segments were categorized as "impaired." Impaired bodies of water have restricted or discouraged uses such as fishing, bathing or water supply. ${ }^{226}$

In a recent report card from the Buffalo River Remedial Advisory Committee, the Buffalo River Watershed got a grade of " $\mathrm{D}$ " in the category of bacterial contamination (Fecal Coliform and E.Coli), largely because of its sewer overflows. ${ }^{227}$ During the rainy summer of 2000, Erie County's five public beaches suffered nearly 100 closings, leading

\footnotetext{
${ }^{224}$ Christopher Kloss and Crystal Calarusse, "Rooftops to Rivers: Green Strategies for Controlling Stormwater and Combined Sewer Overflows" (Natural Resources Defense Council, 2006), available at http://www.nrdc.org/water/pollution/rooftops/rooftops.pdf

${ }_{225}^{22} \mathrm{http} / / /$ oh.water.usgs.gov/nawqa/fs.94056.html

226 "State of the Region: Environment, Stream and Lake Quality," available at http://regionalinstitute.buffalo.edu/sotr/Indicator.cfm?Indicator=554f5afc-1de1-4e61-839e-a10fcc1e4ef8.

${ }^{227} \mathrm{http}: / /$ www.bnriverkeeper.org/programs/tributary/buffalo_river/Buffalo_River_Report_Card_2005.pdf
} 
the County to get labeled "a poster child for sewage problems." ${ }^{228}$ Due to the sewer overflows, the County closes beaches whenever over one half inch of rain falls within 24 hours, until tests show that bacteria levels are safe. ${ }^{229}$

Green design techniques that reduce the flow of rainwater into sewers are much more efficient than building giant new sewer projects to handle the water once it is already in the system. According to New York City Riverkeeper, a \$1,000 investment in "end-ofpipe" sewer projects decreases CSOs by 2,400 gallons. By comparison, the same $\$ 1,000$ investment in:

- Greenstreets could decrease CSOs by 14,800 gallons; ${ }^{230}$

- Street trees could decrease CSOs by 13,170 gallons;

- New green roofs could decrease CSOs by 810 gallons; retrofitted green roofs could decrease CSOs by 865 gallons; and incentivized green roofs could decrease CSOs by 12,000 gallons;

- Rain barrels could decrease CSOs by 9,000 gallons. ${ }^{231}$

Dealing with the CSO problem is not optional; it is required by the federal Clean Water Act. ${ }^{232}$ Using green strategies can greatly reduce the cost of compliance.

Many or most Buffalo houses have gutters that feed directly into the storm sewers instead of allowing the water to be absorbed by soil and plant materials near the house. New housing should be built without these direct connections, and owners of existing housing should disconnect gutters and route them to rain barrels, instead. A Milwaukee study found that attaching rain barrels to 40,000 houses would decrease runoff by 273

\footnotetext{
${ }^{228}$ Mary Pasciak, "A splash of safety,” Buffalo News, August 23, 2002

${ }^{229}$ Tom Earnst and Kerry Jones, "Don't go in the water," Buffalo News, July 28, 2004. See also Elmer Ploetz and Diane E. Hughes, "Great Lakes beaches causing health concerns," Buffalo News, July 1, 2002.

${ }^{230}$ Greenstreets are pocket parks created on formerly paved surfaces such as traffic triangles, roundabouts, and medians. New York City has created over 2,000 greenstreets.

${ }^{231}$ Mike Plumb, "Sustainable Raindrops: Cleaning New York Harbor by Greening the Urban Landscape," available at http://www.riverkeeper.org/campaign.php/pollution/we_are_doing/986

${ }^{232}$ See the EPA's CSO Control Policy at http://www.epa.gov/npdes/pubs/owm0111.pdf.
} 
million gallons per year. In addition, the water from the rain barrels can be used to water grass and plants, to wash cars and sidewalks, and otherwise reduce the need for fresh water.

Landscaping is also an important way to reduce run-off. Adding plants and trees and reducing impervious surfaces such as asphalt and concrete keeps rain water out of the sewers, while at the same time removing pollutants from the air. Plantings can also shad the home and reduce the need for air-conditioning and fans. Every affordable housing project should include a landscaping plan that addresses these issues. 


\section{Conclusion}

The Buffalo region faces a host of challenges in affordable housing and the environment, many of which overlap. Particularly given the reality of climate change, it is short-sighted to build any housing without making a maximal effort to limit the pollution it causes. Global warming is likely to cause massive homelessness with droughts, storm events, and rising sea levels; anyone concerned with homelessness should be concerned with reducing carbon emissions through energy efficiency. Even apart from global warming, our current building practices wreak environmental havoc, imposing substantial costs on society and placing the greatest burdens on people with low incomes.

Fortunately, in the most important areas, greener housing is also more affordable housing, so there is little competition between the two goals. Greener housing is also more healthy housing, a crucial consideration given the dire state of health of our lowincome residents. Affordable housing funders, regulators, designers, developers, and advocates interested in greening their housing will find a wide range of resources and opportunities awaiting them. 


\section{Selected Sources}

Frank S. Alexander, "Land Bank Authorities: a Guide for the Creation and Operation of Local Land Banks," Local Initiatives Support Coalition (2005)

American Forests, "Urban Ecosystem Analysis: Buffalo-Lackawana Area” (2003)

Michael Brower, The Consumer's Guide to Effective Environmental Choices: Practical Advice from the Union of Concerned Scientists (Random House, 1999)

California Sustainable Building Task Force, "The Costs and Financial Benefits of Green Buildings" (2003)

Center for Policy Alternatives, "Progressive Agenda for State Housing Policy 2007"

City of Buffalo, "The Queen City in the 21st Century: the Buffalo Comprehensive Plan"

City of Buffalo Fiscal Year 2007-2008 Budget Overview

City of Buffalo Five Year Consolidated Plan (2003-2008)

City of Buffalo Mayor's Anti-Flipping Task Force, "First Year Report"

Final Report, Erie-Niagara Framework for Regional Growth (October 2006)

Homeless Alliance of Western New York, "PRISM: A Community Solution to Homelessness"

Institute for Local Self-Reliance, “Salvaging Yesterday's Buildings for Tomorrow's Sustainable Communities" (1999)

Christopher Kloss and Crystal Calarusse, "Rooftops to Rivers: Green Strategies for Controlling Stormwater and Combined Sewer Overflows" (Natural Resources Defense Council, 2006)

League of Women Voters, “At Taxpayers' Expense: How Government Policies Encourage Sprawl in Erie and Niagara Counties" (2006 Revised Edition)

Bill McKibben, Deep Economy (Henry Holt, 2007)

National Vacant Properties Campaign, "Blueprint Buffalo"

Mike Plumb, "Sustainable Raindrops: Cleaning New York Harbor by Greening the Urban Landscape"

Meg Power, "FY 2006 Energy Bills Forecast: the Impact on Low-Income Consumers"

Ellen Schloemer et al, "Losing Ground: Foreclosures in the Subprime Market and Their Cost to Homeowners" (December 2006)

Walter Simpson, “A Facitilies Manager's Guide to Green Building Design” (UB Green) 


\section{Student Papers}

Todd Chard, Land Banking in Buffalo

Sean Cooney, Residential Deconstruction in Buffalo: a Viable Alternative to Demolition

Kimberlee DeFazio, Greener Regulations for Buffalo and New York State

Erik Faleski, The Potential of Deconstruction in Buffalo, New York

Andrew Florance, Greener Criteria for Affordable Housing Funding

Constance Giessert, Weatherization Assistance and Low-Income Households

Andre Lindsay, Funding Priorities and Pragmatic Shifts for Affordable Housing

Programs in New York State and the City of Buffalo

Martha McNeill, Buffalo Habitat for Humanity: The Challenges and Prospects of Green Building

Mary O'Donnell, PUSH Buffalo's Community Housing Cooperative: a Case Study in Green Building Rehabilitation

Mark Smith, Belmont Shelter Corporation and Green Design: an Opportunity for Innovation in Western New York

Lauren Weiss, Environmentally Friendly Uses for Vacant Properties in Buffalo

Gary Wilson, The Fruits of New Life: the Prospects of Green Affordable Housing in the Fruitbelt

Katie Woodruff, Home Energy Conservation: Affordable Housing and the Environment

Most of these papers are available at http://green-housing-buffalo.wikispaces.com. 


\section{Acknowledgements}

This article is based in large part on the research, writing, and class participation of the talented students in my "Affordable Housing and the Environment" class: Todd Chard, Sean Cooney, Kimberlee DeFazio, Erik Faleski, Andrew Florance, Constance Giessert, Andre Lindsay, Martha McNeill, Mary O’Donnell, Mark Smith, Lauren Weiss, Gary Wilson, and Katie Woodruff.

I would also like to thank the public officials, non-profit directors, colleagues and others who visited the class, worked with the students, or otherwise helped to shape the project: Anthony Armstrong, Stephen Banko, Aaron Bartley, Modesto Candelario, Michael Clarke, Sara Faherty, Michael Gainer, George Hezel, Sam Hoyt, Michael LoCurto, Laura Mangan, William O'Connell, Walter Simpson, Leonard Skrill, Ronald Talboys, Roberta Vallone, Timothy Wanamaker, and Maria Whyte. 